Review Article

\title{
Vangueria madagascariensis Fruit Tree: Nutritional, Phytochemical, Pharmacological, and Primary Health Care Applications as Herbal Medicine
}

\author{
Alfred Maroyi (iD \\ Medicinal Plants and Economic Development (MPED) Research Centre, Department of Botany, University of Fort Hare, \\ Private Bag X1314, Alice 5700, South Africa \\ Correspondence should be addressed to Alfred Maroyi; amaroyi@ufh.ac.za
}

Received 17 July 2018; Accepted 25 September 2018; Published 1 November 2018

Academic Editor: Marie-Aleth Lacaille-Dubois

Copyright (c) 2018 Alfred Maroyi. This is an open access article distributed under the Creative Commons Attribution License, which permits unrestricted use, distribution, and reproduction in any medium, provided the original work is properly cited.

Vangueria madagascariensis J. F. Gmel. is a plant species regarded as an important fruit tree and medicinal plant in sub-Saharan Africa. This study critically reviewed the nutritional value, phytochemistry, medicinal uses, and pharmacological properties of $V$. madagascariensis. Relevant information on food and medicinal uses of the species was collected from electronic databases such as ISI Web of Knowledge, ProQuest, ScienceDirect, OATD, Scopus, OpenThesis, PubMed, and Google Scholar, and preelectronic literatures were obtained from the university library covering the period 1966 to 2018. Literature studies revealed that $V$. madagascariensis has been integrated into farming systems as a fruit tree to support income and nutritional security of households in the region. Vangueria madagascariensis is used as a herbal medicine against diabetes, gastrointestinal problems, malaria, pain, parasitic worms, and skin diseases. Phytochemical compounds identified from the species include alcohols, aldehydes, esters, furanoids, ketones, and terpenoids. Pharmacological studies revealed that V. madagascariensis extracts have antibacterial, anticonvulsant, antidiabetic, antifungal, anti-inflammatory, antioxidant, cytotoxicity, antimalarial, and antiplasmodial properties. Vangueria madagascariensis should be subjected to detailed nutritional, pharmacological, and toxicological evaluations aimed at correlating the traditional uses of the species and the scientific evidence as well as establishing the efficacy, clinical relevance, safety, and mechanisms of action of the plant extracts and compounds.

\section{Introduction}

Over the last three decades, there has been renewed interest in the phytochemical properties of Vangueria madagascariensis J. F. Gmel. (Figure 1), a plant species with edible fruits and used as a herbal medicine throughout its distributional range. Vangueria madagascariensis belongs to the bedstraw or family Rubiaceae, which is regarded as one of the largest plant groups characterized by about 637 genera and 13000 taxa $[1,2]$. Vangueria madagascariensis is a type of species of the genus Vangueria Juss., which formed a strongly supported group or clade including $V$. esculenta $\mathrm{S}$. Moore, $V$. infausta Burch., and $V$. proschii Briq. based on the results of chloroplast markers trnT-F and rps16 and nuclear ITS [1]. All these four species are characterized by calyx lobes that are narrow, oblong, and triangular in shape [1].
Vangueria genus is made up of about 50 small trees, shrubs, and geofrutices species distributed in sub-Saharan Africa with $V$. madagascariensis also occurring in Madagascar, Mauritius, Réunion, and Seychelles [1, 3]. East Africa, particularly Kenya and Tanzania, is regarded as the centre of diversity of this genus, which is regarded as rare in West Africa [1]. The genus name Vangueria is based on the local Malagasy name "voa vanguer" of $V$. madagascariensis [4-6]. The specific name "madagascariensis" means "of Madagascar" in reference to Madagascar where the specimen type was collected from the species described in 1791 by Johann Friedrich Gmelin (1748-1804), a German naturalist and botanist. English common names of $V$. madagascariensis include common wild medlar, Spanish-tamarind, tamarindof-the-Indies, voa vanga, and wild medlar [7-9]. The synonyms of the species include $V$. acutiloba Robyns, V. edulis 


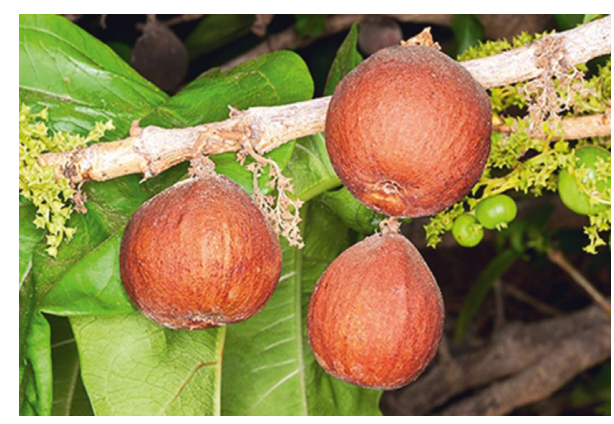

FIGURE 1: Vangueria madagascariensis: a branch showing leaves, flowers, and fruits (photo: Guiseppe Mazza).

Vahl., V. floribunda Robyns, V. madagascariensis subsp. madagascariensis, $V$. madagascariensis var. madagascariensis, V. robynsii Tennant, V. venosa Hochst. ex A. Rich., Vavanga chinensis Rohr, and Vavanga edulis Vahl [3].

Vangueria madagascariensis is a multistemmed deciduous shrub or tree growing up to 15 metres in height. The species is native to Réunion, Tanzania, Democratic Republic of Congo, South Sudan, Angola, Cameroon, Ghana, Benin, Central African Republic, Ethiopia, Eritrea, Madagascar, Mauritius, Mozambique, Nigeria, South Africa, Sudan, Swaziland, Togo, Uganda, Seychelles, and Kenya [3] (Figure 2). The species has been recorded on rocky, sandy red clay, or sandy clay soils in riverine bushlands, evergreen forests, bushed grasslands, rocky outcrops, and termite mounds at an altitude ranging from 0 to 2400 metres above the sea level [3]. Vangueria madagascariensis is cultivated in China, Congo, Cuba, India, northern Australia, Singapore, and Trinidad [8-12]. Considering the existing literature focusing on utilization of $V$. madagascariensis throughout its distributional range, it is evident that different plant parts are used as both food and herbal medicines as these plant parts have several phytochemical compounds and micronutrients required for human nutrition and health [9, 13-17]. Previous research showed that the medicinal and nutritional properties of edible fruits collected from the wild enable local communities to use such plant resources as traditional remedies, at the same time broadening their nutritional options, micronutrients, diet, and vitamins [6, 18, 19]. Vangueria madagascariensis is regarded as a popular fruit tree and medicinal plant, and the plant species has positive effects on human health and well-being [9, 13-17] which are beyond the provisions of basic nutritional requirements. There is no universally accepted definition of functional food and nutraceuticals, but Hailu et al. [20], Shahidi [21], and Wang and $\mathrm{Li}$ [22] argued that functional food and nutraceuticals are natural foods that beneficially affect one or several body functions apart from nutritional effects, influencing both the health and well-being of the consumer. The value of pharmaceutical drugs derived from plants, other natural health products, nutraceuticals, and functional foods are being promoted throughout the world as an alternative strategy for disease risk reduction and reduction in health care costs [21]. It is within this background that the nutritional value, chemical properties, medicinal uses, and biological activities of $V$. madagascariensis were evaluated.

\section{Food Uses}

The fruits of $V$. madagascariensis which are globose, smooth and shiny, and yellowish brown in colour when ripe are edible and highly sought after throughout the distributional range of the species. Although the fruits are mainly collected from the wild, but in clearing land for agricultural purposes, some farmers leave these trees as future sources of fruits. Teklehaimanot [23] identified V. madagascariensis, Strychnos cocculoides Baker, Balanites aegyptiaca (L.) Delile, Vitex doniana Sweet, Berchemia discolor (Klotzsch) Hemsl., Sclerocarya birrea (A. Rich.) Hochst., Borassus aethiopum Mart., Carissa spinarum L., Cordeauxia edulis Hemsl., and Vitellaria paradoxa C. F. Gaertn. as priority indigenous fruit tree species with domestication potential in Ethiopia, Kenya, South Sudan, Sudan, Tanzania, and Uganda. Therefore, V. madagascariensis has been integrated into rural agricultural farming systems in sub-Saharan countries as a strategy to improve food and income security of households in the region. Based on the popularity of its fruits, $V$. madagascariensis was also introduced in home gardens in Congo, Cuba, India, and the West Indies [8-10]. The fruits are marketed in Cuba, Ethiopia, Kenya, Madagascar, Tanzania, and Uganda [8-10, 24, 25].

The fruit pulp of $V$. madagascariensis has a sweet, pleasant chocolate-like flavour when eaten raw and a somewhat astringent and acidic taste like a blend of apple (Malus pumila Miller) and tamarind (Tamarindus indica L.) $[8,26]$. The pulp is also stewed, roasted, added to mealie meal porridge and other food to add flavour, and made into juice, jellies, jam, and puddings [26-29]. In Ethiopia, fruits of $V$. madagascariensis are an important food resource especially during droughts and in times of food shortages [30]. The pulp is a good source of both macrominerals and trace elements such as potassium, zinc, calcium, magnesium, chromium, phosphorus, copper, manganese, and iron ( $\mathrm{Ta}-$ ble 1). The nutritional contribution of the pulp is comparable to other well-known fruits with commercial potential such as Mangifera indica L. and Ziziphus mauritiana Lam (Table 1). Mangifera indica and Ziziphus mauritiana are among the top five important fruit species in the dryland agricultural farming systems in tropical Africa that contribute to household incomes, nutritional needs, and food security [38]. Several amino acids and fatty acids (Table 2) have been identified from the fruit pulp of $V$. madagascariensis, and these include the essential amino acids such as lysine, threonine, histidine, leucine, phenylalanine, valine, isoleucine, and methionine [39, 44]. Research by Mariod et al. [15] revealed that the contribution of conditionally essential amino acids such as tyrosine, arginine, glycine, and cysteine and nonessential amino acids such as glutamic acid, aspartic acid, and serine was close to $50 \%$ (5.9 g out of $14.2 \mathrm{~g} / 100 \mathrm{~g}$ ) of the total amino acids identified from the species (Table 2). The amino acid and fatty acid constituents and other physicochemical properties of $V$. madagascariensis make the species a valuable source of these nutrients when compared with the nutritional value of Mangifera indica and Ziziphus 


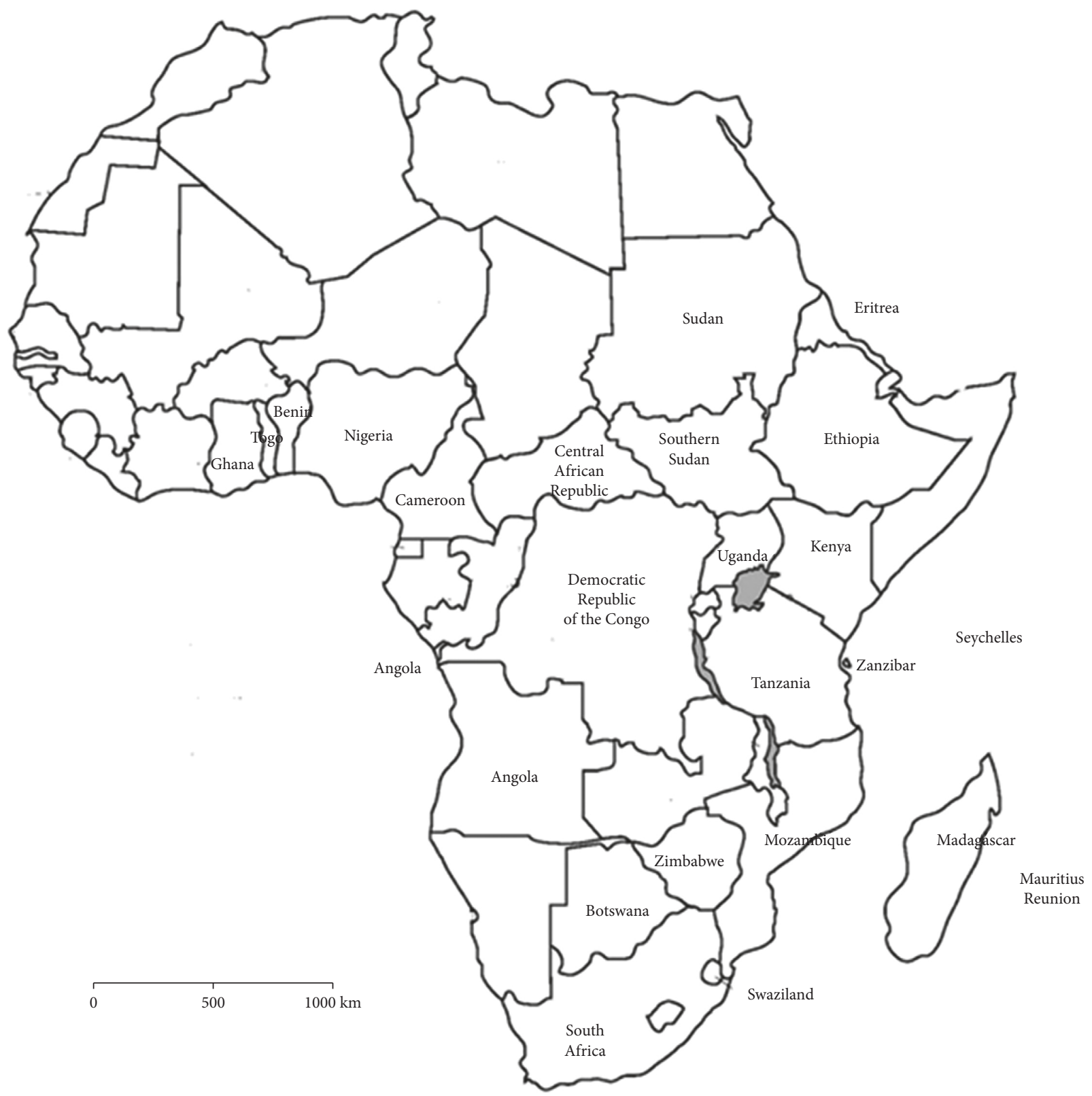

FIgURe 2: Natural distribution of Vangueria madagascariensis.

mauritiana and the $\mathrm{FAO} / \mathrm{WHO} / \mathrm{UNU}$ dietary reference intakes or $\mathrm{RDA}$ required to meet essential nutrients for a healthy person (Tables 1 and 2). Pino et al. [9] identified sixty volatile constituents from the fruit pulp of $V$. madagascariensis (Table 3). The major phytochemical compounds identified include alcohols, aldehydes, esters, furanoids, ketones, and terpenoids (Table 3). Pino et al. [9] argued that the acidic and pungent taste associated with the fruit pulp of $V$. madagascariensis can be explained by the higher amounts of fatty acids as shown in Table 2.

\section{Medicinal Uses of Vangueria madagascariensis}

The seeds, bark, leaves, fruits, roots, and stem bark of $V$. madagascariensis are utilized in monotherapeutic or multitherapeutic applications in Eritrea, Kenya, Madagascar, Mauritius, Sudan, and Tanzania (Table 4). Bark, fruit, leaf, and root maceration of $V$. madagascariensis is taken by mouth for diabetes in Madagascar [47], Mauritius [14, 48], and Sudan $[49,50]$. Bark, leaf, root bark, and stem bark infusion of $V$. madagascariensis is taken by mouth for bloody diarrhoea in Tanzania [45], dysentery in Mauritius [47], and stomach problems in Kenya [58]. Root bark and root infusion of $V$. madagascariensis is taken by mouth for intestinal worms in Eritrea [52] and Tanzania [8, 45]. Bark, root bark, and stem bark maceration of $V$. madagascariensis is taken by mouth for malaria in Kenya [53-57] and Tanzania $[8,45,51]$. In Tanzania, the leaf, root, root bark, and stem bark maceration of $V$. madagascariensis is taken by mouth for abdominal pains, asthma, convulsions, gonorrhoea, hepatitis, hernia, and oedema $[45,51]$. Fruit decoction 
TABLE 1: Nutritional composition of the fruit pulp of V. madagascariensis compared with nutritional values of Mangifera indica and Ziziphus mauritiana and the recommended dietary allowance (RDA).

\begin{tabular}{|c|c|c|c|c|}
\hline Caloric and nutritional composition & Value & $\begin{array}{c}\text { Ziziphus } \\
\text { mauritiana }\end{array}$ & $\begin{array}{c}\text { Mangifera } \\
\text { indica } \\
\end{array}$ & $\begin{array}{c}\text { Recommended dietary } \\
\text { allowance (RDA) }\end{array}$ \\
\hline Ascorbic acid $(\mathrm{mg} / 100 \mathrm{~g})$ & 4.7 & $15.0-43.8$ & $16.0-46.5$ & $100-120$ \\
\hline Calcium $(\mathrm{mg} / 100 \mathrm{~g})$ & 25 & $160-254$ & $14.0-30.6$ & $1000-1300$ \\
\hline Carbohydrates (\%) & 28 & $79.5-83.2$ & $16.9-27.3$ & $45-65$ \\
\hline Copper $(\mathrm{mg} / 100 \mathrm{~g})$ & $0.5 \pm 0.2$ & $0.7-1.5$ & 0.1 & $1-3$ \\
\hline Chromium $(\mathrm{mg} / 100 \mathrm{~g})$ & $0.2 \pm 0.1$ & 0.1 & $0.01-0.02$ & $0.02-0.2$ \\
\hline Energy value $(\mathrm{kJ} / 100 \mathrm{~g})$ & 498 & $1516-1575$ & 74 & 2200 \\
\hline Fibre $(\%)$ & 4.7 & $4.9-7.3$ & $1.1-4.8$ & $25-38$ \\
\hline Iron $(\mathrm{mg} / 100 \mathrm{~g})$ & $1.1-5.2$ & $2.1-4.3$ & $1.3-8.4$ & $8-15$ \\
\hline Lipid (\%) & 0.1 & - & 0.1 & 300 \\
\hline Magnesium (mg/100g) & 39 & $83-150$ & $1.5-7.5$ & $310-320$ \\
\hline Manganese (mg/100 g) & $2.4 \pm 1.1$ & $0.7-1.6$ & $6.2-7.8$ & $1-5$ \\
\hline Niacin $(\mathrm{mg} / 100 \mathrm{~g})$ & 0.61 & $0-7-0.9$ & 0.6 & $40-70$ \\
\hline Phosphorus (mg/100 g) & 36.6 & $87-148$ & 16 & 1250 \\
\hline Potassium (mg/100 g) & 521 & $1865-2441$ & $10.2-205$ & 4700 \\
\hline Protein $(\%)$ & 1.4 & $7.9-8.7$ & 0.6 & 34 \\
\hline Riboflavin (mg/100 g) & 0.04 & 0.02 & 0.6 & $3-10$ \\
\hline Sodium $(\mathrm{mg} / 100 \mathrm{~g})$ & 28 & $185-223$ & $26-91.1$ & 2300 \\
\hline Thiamine $(\mathrm{mg} / 100 \mathrm{~g})$ & 0.05 & 0.03 & 0.05 & 6.1 \\
\hline $\begin{array}{l}\text { Total flavonoid content } \\
\text { (mg RE/g fresh weight) }\end{array}$ & 8.00 to 8.20 & $8.4-22.0$ & & 1000 \\
\hline $\begin{array}{l}\text { Total phenolic content } \\
\text { (mg GAE/g dry weight) }\end{array}$ & 37.00 to 61.22 & $172.1-309.5$ & 652.6 & 2500 \\
\hline $\begin{array}{l}\text { Total proanthocyanidins } \\
\text { (mg CE/g fresh weight) }\end{array}$ & 134.57 to 159.50 & - & 7.9 & 1000 \\
\hline Zinc $(\mathrm{mg} / 100 \mathrm{~g})$ & $0.4 \pm 0.2$ & $0.6-0.9$ & 0.04 & $8-11$ \\
\hline
\end{tabular}

Sources: Ramalingum and Mahomoodally [14]; Nigam et al. [31]; Kipkemboi [32]; Nyanga et al. [33]; Pareek et al. [34]; Ara et al. [35]; da Silva et al. [36]; Sajib et al. [37].

of $V$. madagascariensis is taken by mouth for back pain and mouth infections in Kenya [46,58], while root decoction is taken orally as a purgative in Eritrea [52]. In Sudan, the fruit and seed decoction of $V$. madagascariensis is taken orally as a remedy for hypertension, kidney problems, and tumour $[50,59]$, while bark and leaf decoction is taken orally for palpitations and nausea in Mauritius [47]. Multitherapeutic applications of $V$. madagascariensis involve mixing leaves of the species with leaves of Jatropha curcas L., Azadirachta indica A. Juss., and Ipomoea pes-caprae (L.) R. Br. as a herbal medicine for abscesses, carbuncle, and scurf in Mauritius [14]. In Mauritius, the leaf decoction of $V$. madagascariensis is mixed with the leaves of Jatropha curcas, Toddalia asiatica (L.) Lam., and Sporobolus africanus (Poir.) Robyns \& Tournay as a mouthwash [48].

\section{Phytochemistry and Pharmacological Properties of Vangueria madagascariensis}

Phytochemical screening of the bark, fruits, leaves, kernel oil, seeds, stems, and stem bark has shown the presence of fibre, carbohydrates, proteins, and several classes of phytochemicals such as volatile and nonvolatile metabolites (Table 5), and chemical structures of representative phytochemical compounds are shown in Figure 3. The majority of the phytochemicals were identified using highperformance liquid chromatography (HPLC-DAD) with diode array detection (DAD), mass spectrometry (MS), gas chromatography-mass spectrometry (GC/MS), nuclear magnetic resonance (NMR) spectroscopy, and gas chromatography (GC) (Table 5). Each fruit of $V$. madagascariensis has 4 to 5 seeds, and the seed kernel contains considerable amount of oil which is higher than that of conventional oil seeds such as groundnut (Arachis hypogaea L.), cottonseed (Gossypium hirsutum L.), and sunflower (Helianthus annuus L.) [62]. Some of the phytochemical compounds such as flavonoids identified from V. madagascariensis are known to have antiallergic, antiinflammatory, antimicrobial, antiproliferative, antioxidant, enzyme inhibition, and oestrogenic activities, synergism with antibiotics, and suppression of bacterial virulence [63-66]. Research by Prochazkova et al. [65] revealed that the antioxidant activities of flavonoids involve quenching free radical elements, metal chelation, suppression of enzymes involved in free radical scavenging, and stimulation of enzymes that activate antioxidant activities. Research has also revealed that food resources characterized by high levels of flavonoids and related phenolic compounds may reduce the risk of cardiovascular diseases [67]. Pereira et al. [63] argued that the structural figure of phenolic compounds has the potential to interact with several proteins; mainly, they have a hydrophobic benzenoid ring and hydrogen-binding properties which enhance their capacity to be antioxidants by inhibiting several enzymes that catalyze radical generation, including xanthine oxidase, cytochrome P450 isoforms, cyclooxygenase, and lipoxygenase enzymes. The different 
TABLE 2: Fatty acids and amino acid composition of fruit pulp of $V$. madagascariensis compared with nutritional values of Mangifera indica and Ziziphus mauritiana and the recommended dietary allowance (RDA).

\begin{tabular}{|c|c|c|c|c|}
\hline Chemical composition & Value & Ziziphus mauritiana & Mangifera indica & Recommended dietary allowance (RDA) \\
\hline \multicolumn{5}{|l|}{ Amino acids (g/100 g) } \\
\hline Arginine & $1.1 \pm 0.6$ & 0.7 & 0.02 & - \\
\hline Aspartic acid & $1.5 \pm 0.7$ & 1.3 & 0.04 & - \\
\hline Glutamic acid & $1.9 \pm 0.6$ & 1.3 & 0.06 & - \\
\hline Glycine & $0.8 \pm 0.1$ & 0.3 & 0.02 & - \\
\hline Histidine & $0.7 \pm 0.6$ & 0.1 & 0.01 & 10 \\
\hline Isoleucine & $0.82 \pm 0.5$ & 0.3 & 0.02 & 20 \\
\hline Leucine & $1.6 \pm 0.6$ & 0.5 & 0.03 & 39 \\
\hline Lysine & $0.8 \pm 0.4$ & 0.3 & 0.04 & 30 \\
\hline Methionine + cysteine & $0.21 \pm 0.1$ & 0.1 & 0.01 & 15 \\
\hline Phenylalanine + tyrosine & $1.3 \pm 0.6$ & 0.3 & 0.02 & 25 \\
\hline Serine & $0.7 \pm 0.4$ & 0.3 & 0.02 & - \\
\hline Threonine & $0.74 \pm 0.4$ & 0.3 & 0.02 & 15 \\
\hline Valine & $1.0 \pm 0.5$ & 0.4 & 0.03 & 26 \\
\hline \multicolumn{5}{|l|}{ Fatty acids $(\mathrm{mg} / \mathrm{kg})$} \\
\hline Acetic acid & 0.12 & - & - & - \\
\hline Butyric acid & 0.12 & - & - & - \\
\hline Decanoic acid & 0.08 & - & - & - \\
\hline Dodecanoic acid & 0.30 & 0.05 & $0.02-0.5$ & - \\
\hline Heptanoic acid & 1.70 & - & $0.04-0.2$ & - \\
\hline Hexadecanoic acid & 5.19 & 4.0 & $2.2-14.6$ & - \\
\hline Hexanoic acid & 1.80 & - & - & - \\
\hline Octanoic acid & 1.95 & - & - & - \\
\hline Octadecanoic acid & 0.69 & 2.2 & $1.6-3.4$ & - \\
\hline Pentadecanoic acid & 0.61 & - & $0.02-0.04$ & - \\
\hline Pentanoic acid & 0.01 & - & - & - \\
\hline Undecanoic acid & 0.04 & - & - & - \\
\hline Tetradecanoic acid & 4.50 & 0.1 & $0.1-1.1$ & - \\
\hline (Z)-9-Octadecenoic acid & 0.06 & - & - & - \\
\hline
\end{tabular}

Sources: Pino et al. [9]; Mariod et al. [15]; FAO/WHO/UNU [38]; Institute of Medicine [39]; Sena et al. [40]; Bally [41]; Vilela et al. [42]; Deshpande et al. [43].

parts of $V$. madagascariensis are associated with several fatty acids $[16,60,61]$, and these compounds are known to have a wide range of physiological effects such as cardiovascular function, immune system regulation, neuronal development, regulation of plasma lipid levels, insulin regulation, and visual function [68]. Several studies done elsewhere demonstrated the importance of dietary intake of fatty acids as they lead to reduced blood pressure, they lower the risk of heart attack and arteriosclerosis risks, and these compounds are associated with antimicrobial properties and synthetic accessibilities [69-71]. Desbois and Smith [71] argued that the antimicrobial properties of fatty acids are based on their ability to disturb and distort the oxidative phosphorylation process and the electron transport chain process, thereby disturbing the cellular energy production, leading to reduction of enzymatic activity, reduced nutrient uptake, and production of toxic peroxidation. The phytochemicals detected in various parts of $V$. madagascariensis may be used to justify some of the medicinal uses of this species recorded in Table 4 and also documented antibacterial [13, 60, 72], anticonvulsant [60], antidiabetic [13, 73], antifungal [60, 74], anti-inflammatory [60], antioxidant [13, 17], cytotoxicity [17], antimalarial, and antiplasmodial $[55,56]$ activities.

4.1. Antibacterial Activities. Bishay et al. [60] assessed antibacterial properties of leaf and bark ethyl acetate, chloroform, and $n$-hexane extracts of $V$. madagascariensis against Pseudomonas aeruginosa, Bacillus cereus, Escherichia coli, Klebsiella pneumoniae, Micrococcus luteus, and Staphylococcus aureus using the modified diffusion method with dimethylformamide (DMF) and gentamicin $(5 \mu \mathrm{g} / \mathrm{ml})$ as negative and positive controls, respectively (Table 6). The extracts showed activities with the zone of inhibition stretching from $4 \mathrm{~mm}$ to $18 \mathrm{~mm}$ which was comparable to the zone of inhibition of $10 \mathrm{~mm}$ to $14 \mathrm{~mm}$ demonstrated by gentamicin, the control. The minimum inhibitory concentration (MIC) values ranged from $6.3 \mu \mathrm{g} / \mathrm{ml}$ to $75 \mu \mathrm{g} / \mathrm{ml}$ [60]. Ramalingum and Mahomoodally [13] evaluated antibacterial properties of methanol and crude fruit, leaf, and seed extracts of $V$. madagascariensis making use of the disc diffusion and microtitre dilution broth method against Escherichia coli and Staphylococcus aureus with streptomycin sulphate and gentamicin sulphate as positive controls (Table 6). The crude ripe and unripe fruit extracts and methanol leaf and seed extracts exhibited some antibacterial properties with the zone of inhibition ranging $8.3 \mathrm{~mm}$ to $12.7 \mathrm{~mm}$ and MIC values ranging from $6.3 \mathrm{mg} / \mathrm{mL}$ to $25.0 \mathrm{mg} / \mathrm{mL}$ [13]. Mahomoodally and Dilmohamed [72] evaluated antibacterial activities of fruit and leaf extracts of $V$. madagascariensis against Klebsiella spp., Acinetobacter spp., Enterococcus faecalis, Pseudomonas aeruginosa, Staphylococcus aureus, Proteus spp., Streptococcus spp. and 
TABle 3: Volatile phytochemical compounds identified from $V$. madagascariensis fruits.

\begin{tabular}{|c|c|}
\hline Phytochemical composition & Values $(\mathrm{mg} / \mathrm{kg})$ \\
\hline $\begin{array}{l}\text { Alcohol } \\
\alpha \text {-Terpineol } \\
\text { 2-Methyl-3-buten-2-ol } \\
\text { Benzyl alcohol } \\
\text { Ethanol } \\
\text { 2-Butanol } \\
\text { Isoamyl alcohol } \\
\text { 2-Methylbutanol } \\
\text { 3-Methyl-2-butenol } \\
\text { Octanol } \\
\text { Furfuryl alcohol } \\
\text { (Z)-3-Hexenol } \\
\text { Hexanol } \\
\end{array}$ & $\begin{array}{l}0.10 \\
1.07 \\
0.25 \\
0.08 \\
0.54 \\
1.38 \\
0.24 \\
0.12 \\
0.51 \\
1.15 \\
0.06 \\
2.40 \\
\end{array}$ \\
\hline $\begin{array}{l}\text { Aldehyde } \\
\text { 2-Methylbutanal } \\
\text { 2-Furfural } \\
\text { 3-Furfural } \\
\text { 2-Phenylacetaldehyde } \\
\text { Acetaldehyde } \\
\text { Benzaldehyde } \\
\text { (E)-2-Octenal } \\
\text { (E,E)-2,6-Hexadienal } \\
\text { (E)-4-Undecenal } \\
\text { (E)-4-Nonenal } \\
\text { (E)-4-Decenal } \\
\text { (E,E)-4,4-Heptadienal } \\
\text { (E,Z)-4,4-Heptadienal } \\
\text { Heptanal } \\
\text { Hexanal } \\
\text { Isovaleraldehyde }\end{array}$ & $\begin{array}{c}0.43 \\
11.93 \\
2.43 \\
2.12 \\
<0.01 \\
2.12 \\
3.84 \\
0.08 \\
0.51 \\
0.17 \\
0.09 \\
0.28 \\
0.29 \\
0.83 \\
0.82 \\
0.44\end{array}$ \\
\hline $\begin{array}{l}\text { Ester } \\
\text { Methyl benzoate } \\
\text { Methyl 2-phenylacetate } \\
\text { 2-Phenylethyl acetate } \\
\text { Methyl hexanoate } \\
\text { Methyl (Z)-3-hexenoate } \\
\text { Methyl (E)-2-hexenoate } \\
\text { Methyl octanoate } \\
\text { Methyl decanoate } \\
\text { Methyl butyrate } \\
\text { Methyl (E)-cinnamate } \\
\text { Methyl 9,12,15-octadecatrienoate } \\
\text { Methyl (Z)-9-hexadecenoate } \\
\text { Methyl hexadecanoate } \\
\text { Methyl octadecanoate } \\
\text { Methyl pentanoate } \\
\text { Methyl salicylate } \\
\text { Methyl tetradecanoate }\end{array}$ & $\begin{array}{c}0.56 \\
0.34 \\
0.54 \\
2.14 \\
<0.01 \\
<0.01 \\
1.98 \\
0.05 \\
0.08 \\
0.04 \\
0.11 \\
0.51 \\
0.39 \\
0.10 \\
0.10 \\
0.08 \\
<0.01 \\
\end{array}$ \\
\hline $\begin{array}{l}\text { Monoterpene } \\
\text { Terpinolene } \\
\text { p-Cymene } \\
\text { Limonene }\end{array}$ & $\begin{array}{l}0.09 \\
0.01 \\
2.48\end{array}$ \\
\hline $\begin{array}{l}\text { Furan } \\
\text { 2-Propylfuran } \\
\text { 5-Methylfurfural }\end{array}$ & $\begin{array}{c}<0.01 \\
0.04\end{array}$ \\
\hline $\begin{array}{l}\text { Indole } \\
1 \mathrm{H} \text {-indole }\end{array}$ & 0.04 \\
\hline $\begin{array}{l}\text { Ketone } \\
\text { 2-Heptanone }\end{array}$ & 0.28 \\
\hline
\end{tabular}

TABLE 3: Continued.

\begin{tabular}{lc}
\hline Phytochemical composition & Values $(\mathrm{mg} / \mathrm{kg})$ \\
\hline 2-Pentanone & 0.41 \\
3-Penten-2-one & 0.10 \\
Acetoin & 0.04 \\
5-Butyldihydro-2(3H)-furanone & $<0.01$ \\
5-Ethyldihydro-2(3H)-furanone & 1.95 \\
$\boldsymbol{\delta}$-Octalactone & 0.12 \\
$\boldsymbol{\gamma}$-Dodecalactone & 0.04 \\
\hline Norisoprenoids & \\
4-Ketoisophorone & 0.02 \\
\hline
\end{tabular}

Source: Pino et al. [9].

methicillin-resistant Staphylococcus aureus (MRSA), and Escherichia coli using the microdilution broth method with chloramphenicol and gentamicin as positive controls (Table 6). The extracts demonstrated antibacterial properties with MIC values ranging from $<0.1 \mathrm{mg} / \mathrm{mL}$ to $12.5 \mathrm{mg} / \mathrm{mL}$. The authors found that mixing of antiobiotics such as chloramphenicol and gentamicin with $V$. madagascariensis extracts resulted in significant antibacterial properties by reducing the MICs [72]. These antibacterial activities exhibited by different extracts of $V$. madagascariensis corroborate the traditional use of the species as herbal concoction against bacterial and other microbial infections causing bloody diarrhoea and gonorrhoea in Tanzania [45], carbuncle and dysentery in Mauritius $[14,48]$, mouth infections in Kenya and Mauritius [48, 58], and stomach problems in Kenya [58].

4.2. Anticonvulsant Activities. The activities of the different fractions and the total ethanolic extracts of both leaves and stem bark of $V$. madagascariensis on the central nervous system were evaluated by performing assays of their effect on motor coordination (rotarod test) and pentylene tetrazoleinduced convulsion [60]. The total ethanolic extracts as well as the other fractions of both leaves and stem-bark attained a central nervous system depressant activity. The n-butanol and $n$-hexane extracts of the leaves, $n$-hexane and chloroform extracts the stem-bark at $400 \mathrm{mg} / \mathrm{kg}$ have anticonvulsant properties against pentylene tetrazole induced convulsions in comparison with carbamazepine. The $\mathrm{n}$-butanol and n-hexane extracts of the leaves, $\mathrm{n}$-hexane and chloroform extracts of the stem-bark at $400 \mathrm{mg} / \mathrm{kg}$ exhibited anticonvulsant properties against pentylene tetrazole induced convulsions in rats in comparison with carbamazepine [60]. The anticonvulsant properties demonstrated by the extracts of $V$. madagascariensis corroborate the usage of stem bark of the species as herbal concoction against convulsions in Tanzania [60].

4.3. Antidiabetic Activities. Ramalingum and Mahomoodally [14] evaluated antidiabetic activities of methanol and crude fruit, leaf and seed extracts of $V$. madagascariensis using $\alpha$-amylase, $\alpha$-glucosidase and a modified glucose based colorimetric and glucose movement assays with acarbose as the control (Table 6). The crude and methanol extracts 
Table 4: Medicinal applications of Vangueria madagascariensis.

\begin{tabular}{|c|c|c|c|}
\hline Medicinal use & Parts of the plant used & Country & References \\
\hline Abdominal pains & Roots & Tanzania & {$[45]$} \\
\hline $\begin{array}{l}\text { Abscesses, carbuncle, and } \\
\text { scurf }\end{array}$ & $\begin{array}{l}\text { Leaf decoction mixed with leaves of Jatropha curcas } \\
\text { L., Azadirachta indica A. Juss., and Ipomoea pes- } \\
\text { caprae (L.) R. Br. }\end{array}$ & Mauritius & {$[14]$} \\
\hline Asthma & Leaves & Tanzania & {$[45]$} \\
\hline Back pain & Fruits & Kenya & {$[46]$} \\
\hline Bloody diarrhoea & Stem bark & Tanzania & {$[45]$} \\
\hline Palpitations & Bark and leaves & Mauritius & {$[47]$} \\
\hline Convulsions & Stem bark & Tanzania & [45] \\
\hline Diabetes & Bark, leaves, fruits, and roots & $\begin{array}{l}\text { Madagascar, Mauritius, and } \\
\text { Sudan }\end{array}$ & {$[14,47-50]$} \\
\hline Dysentery & Bark and leaves & Mauritius & [47] \\
\hline Gonorrhoea & Stem bark & Tanzania & [45] \\
\hline Hepatitis & Roots and root bark & Tanzania & {$[45,51]$} \\
\hline Hernia & Stem bark & Tanzania & {$[45]$} \\
\hline Hypertension & Fruits & Sudan & {$[50]$} \\
\hline Intestinal worms & Roots and root bark & Eritrea and Tanzania & {$[8,51,52]$} \\
\hline Kidney problems & Fruits & Sudan & {$[50]$} \\
\hline Malaria & Bark, roots, and stem bark & Kenya and Tanzania & {$[8,45,51,53-57]$} \\
\hline Mouth infections & Roots & Kenya & {$[58]$} \\
\hline Mouthwash & $\begin{array}{l}\text { Leaf decoction taken orally mixed with leaves of } \\
\text { Jatropha curcas, Toddalia asiatica (L.) Lam., and } \\
\text { Sporobolus africanus (Poir.) Robyns \& Tournay }\end{array}$ & Mauritius & [48] \\
\hline Nausea & Bark and leaves & Mauritius & [47] \\
\hline Oedema & Stem bark & Tanzania & {$[45]$} \\
\hline Purgative & Roots & Eritrea & {$[52]$} \\
\hline Stomach problems & Roots & Kenya & {$[58]$} \\
\hline Tumour & Seeds & Sudan & [59] \\
\hline
\end{tabular}

exhibited inhibitory activities against $\alpha$-amylase with half maximal inhibitory concentration $\left(\mathrm{IC}_{50}\right)$ values varying from $1.1 \mathrm{mg} / \mathrm{mL}$ to $29.6 \mathrm{mg} / \mathrm{mL}$ which was comparable to acarbose with $\mathrm{IC}_{50}$ value of $0.1 \mathrm{mg} / \mathrm{mL}$. The extracts that exhibited activities against $\alpha$-glucosidase where unripe fruit decoction, ripe fruit methanol, unripe fruit methanol, leaf decoction exhibited $\mathrm{IC}_{50}$ values stretching from $0.4 \mathrm{mg} / \mathrm{mL}$ to $3.3 \mathrm{mg} / \mathrm{mL}$ which were significantly lower than $\mathrm{IC}_{50}$ value of $5.0 \mathrm{mg} / \mathrm{mL}$ demonstrated by the control, acarbose. The kinetic evaluations showed a mixed non-competitive type of inhibition. Beidokhti et al. [73] evaluated the inhibition of pancreatic $\alpha$-amylase and yeast $\alpha$-glucosidase by ethanolic bark and leaf extracts of $V$. madagascariensis (Table 6). The showed activities against both $\alpha$-glucosidase and $\alpha$-amylase and characterized by $\mathrm{IC}_{50}$ values of $1.8 \mu \mathrm{g} / \mathrm{mL}$ and $11.6 \mu \mathrm{g} / \mathrm{mL}$, respectively [73]. The observed antidiabetic activities of $V$. madagascariensis extracts support the use of the bark, leaves, fruits and roots of the species as herbal medicine against diabetes in Madagascar, Mauritius and Sudan $[14,47-50]$.

4.4. Antifungal Activities. Bishay et al. [60] assessed antifungal properties of bark and leaf aqueous, n-hexane, chloroform, ethyl acetate extracts of $V$. madagascariensis against Candida albicans using the modified diffusion method with clotrimazole $(5 \mu \mathrm{g} / \mathrm{ml})$ as the positive control (Table 6). The bark and leaf extracts showed antifungal properties with zone of inhibition stretching from $9 \mathrm{~mm}$ to
$20 \mathrm{~mm}$ which was comparable to zone of inhibition of $14 \mathrm{~mm}$ demonstrated by clotrimazole, the control. The MIC values stretched from $13.0 \mu \mathrm{g} / \mathrm{ml}$ to $55.0 \mu \mathrm{g} / \mathrm{ml}$ and clotrimazole, the control exhibited MIC value of $4.0 \mu \mathrm{g} / \mathrm{ml}$ [60]. Similarly, Karim et al. [74] assessed antifungal properties of chloroform fruit extract of $V$. madagascariensis against Candida albicans and Aspergillus Niger using agar diffusion assay with ampicillin as positive control (Table 6). The chloroform fruit extract showed activities with zone of inhibition stretching from $14 \mathrm{~mm}$ to $15 \mathrm{~mm}$ [74]. These antifungal activities displayed by the different extracts of $V$. madagascariensis demonstrate the potential of the species in the management of fungal and microbial infections.

4.5. Anti-inflammatory Activities. Bishay et al. [60] assessed anti-inflammatory properties of bark and leaf aqueous, ethyl acetate, chloroform and n-hexane extracts of $V$. madagascariensis using the carrageenan-induced rat paw oedema model. Potent anti-inflammatory activities were observed after 2 hrs and continued for 4 hrs with all the extracts [60]. These findings corroborate the traditional use of $V$. madagascariensis as herbal concoction for abdominal pains in Tanzania [45], back pain in Kenya [46] and other various inflammatory ailments and diseases including skin infections and body injury that may lead to cell damage and death.

4.6. Antioxidant Activities. Ramalingum and Mahomoodally [13] evaluated antioxidant properties of methanol and 
TABLE 5: Nutritional and phytochemical composition of Vangueria madagascariensis.

\begin{tabular}{|c|c|c|c|c|}
\hline Compound & Value & Method of compound analysis & Plant part & References \\
\hline Carbohydrates (\%) & 14.6 & & Seeds & {$[16]$} \\
\hline Fibre (\%) & $14.0 \pm 0.2$ & & Seeds & {$[16]$} \\
\hline Moisture (\%) & $6.4 \pm 0.1$ & & Seeds & {$[16]$} \\
\hline Protein (\%) & $22.2 \pm 0.3$ & & Seeds & {$[16]$} \\
\hline $\begin{array}{l}\text { Total flavonoid content (mg RE/g fresh } \\
\text { weight) }\end{array}$ & $6.7-9.0$ & - & Leaves, fruits, and seeds & [13] \\
\hline $\begin{array}{l}\text { Total phenolic content (mg GAE/g fresh } \\
\text { weight) }\end{array}$ & $35.0-122.2$ & - & Leaves, fruits, and seeds & {$[13]$} \\
\hline $\begin{array}{l}\text { Total proanthocyanidins (mg CE/g fresh } \\
\text { weight) }\end{array}$ & $42.5-185.7$ & - & Leaves, fruits, and seeds & {$[13]$} \\
\hline \multicolumn{5}{|l|}{ Vitamin E } \\
\hline$\alpha$-Tocopherol (mg/100g) & $28.5-31.6$ & GC/MS and HPLC & Kernel oil & {$[16]$} \\
\hline$\beta$-Tocopherol (mg/100 g) & $63.8-65.7$ & GC/MS and HPLC & Kernel oil & {$[16]$} \\
\hline$\gamma$-Tocopherol $(\mathrm{mg} / 100 \mathrm{~g})$ & $4.7-5.1$ & GC/MS and HPLC & Kernel oil & {$[16]$} \\
\hline$\delta$-Tocopherol $(\mathrm{mg} / 100 \mathrm{~g})$ & $8.4-10.5$ & GC/MS and HPLC & Kernel oil & {$[16]$} \\
\hline \multicolumn{5}{|l|}{ Alcohol } \\
\hline Cetyl alcohol & - & NMR & Leaves and stem bark & {$[60]$} \\
\hline \multicolumn{5}{|l|}{ Cyclitol } \\
\hline $\begin{array}{l}\text { Flavonoid } \\
\text { Kaempferol-3-O-rhamnoside-7-O- } \\
\text { rutinoside }\end{array}$ & - & NMR & Leaves and stem bark & {$[60]$} \\
\hline \multicolumn{5}{|l|}{ Coumarin } \\
\hline \multicolumn{5}{|l|}{ Phenolics } \\
\hline Chlorogenic acid (mg/100g) & $1.0-1.2$ & HPLC-DAD and MS & Leaves and seeds & {$[17]$} \\
\hline Ferulic acid $(\mathrm{mg} / 100 \mathrm{~g})$ & $0.03-0.06$ & HPLC-DAD and MS & Leaves and seeds & {$[17]$} \\
\hline Gallic acid $(\mathrm{mg} / 100 \mathrm{~g})$ & $0.004-0.06$ & HPLC-DAD and MS & Bark, leaves, and seeds & {$[17]$} \\
\hline Hydroxybenzoic acid (mg/100 g) & $0.03-0.05$ & HPLC-DAD and MS & Leaves and seeds & {$[17]$} \\
\hline $\mathrm{p}$-Coumaric acid $(\mathrm{mg} / 100 \mathrm{~g})$ & $0.005-0.03$ & $\begin{array}{l}\text { GC, HPLC-DAD, MS, and } \\
\text { NMR }\end{array}$ & $\begin{array}{c}\text { Leaves, seeds, stems, and stem } \\
\text { bark }\end{array}$ & {$[17,60]$} \\
\hline Protocatechuic acid & - & NMR & Leaves and stem bark & {$[60]$} \\
\hline Scopoletin & - & NMR & Leaves and stem bark & {$[60]$} \\
\hline Syringic acid $(\mathrm{mg} / 100 \mathrm{~g})$ & $0.007-0.21$ & HPLC-DAD and MS & Bark, leaves, and seeds & {$[17]$} \\
\hline Vanillic acid & - & NMR & Leaves and stem bark & {$[60]$} \\
\hline Vanillin $(\mathrm{mg} / 100 \mathrm{~g})$ & $0.02-0.05$ & HPLC-DAD and MS & Bark, leaves, and seeds & [17] \\
\hline \multicolumn{5}{|l|}{ Monomethyl ester } \\
\hline 4,4-Dimethyl pimelate (\%) & 0.1 & GC/MS & Leaves and stems & {$[60]$} \\
\hline Methyl margarate (\%) & 1.1 & GC/MS & Leaves and stems & {$[60]$} \\
\hline Methyl myristate (\%) & 3.1 & GC/MS & Leaves and stems & {$[60]$} \\
\hline Methyl palmitate (\%) & 44.7 & GC/MS & Leaves and stems & {$[60]$} \\
\hline Methyl stearate (\%) & 10.5 & GC/MS & Leaves and stems & {$[60]$} \\
\hline Pentadecyl cyclohexanecarboxylate (\%) & 2.2 & GC/MS & Leaves and stems & {$[60]$} \\
\hline \multicolumn{5}{|l|}{ Fatty acids } \\
\hline 9-Hexadecenoic acid (\%) & 0.4 & GC/MS & Leaves and stems & {$[60]$} \\
\hline 9-Dodecenoic acid (\%) & 0.2 & GC/MS & Leaves and stems & {$[60]$} \\
\hline 8,11 -Octadecadienoic acid (\%) & 8.9 & GC/MS & Leaves and stems & {$[60]$} \\
\hline $9,12,15$-Octadecatrienoic acid (\%) & 12.1 & GC/MS & Leaves and stems & {$[60]$} \\
\hline 11-Octadecenoic acid (\%) & 0.1 & GC/MS & Leaves and stems & {$[60]$} \\
\hline Arachidic acid (\%) & $2.2-5.9$ & GC, GC/MS, and HPLC & Kernel oil and leaves & {$[16,61]$} \\
\hline Capric acid (\%) & $3.7-4.1$ & GC, GC/MS, and HPLC & Kernel oil & {$[16]$} \\
\hline Docosanoic acid (\%) & 2.7 & GC/MS & Leaves and stems & {$[60]$} \\
\hline Dodecanoic acid (\%) & 0.2 & GC/MS & Leaves and stems & {$[60]$} \\
\hline Eicosanoic acid (\%) & 6.0 & GC/MS & Leaves and stems & {$[60]$} \\
\hline Erucic acid (\%) & $0.2-0.7$ & GC/MS and HPLC & Kernel oil & {$[16]$} \\
\hline Heneicosanoic acid (\%) & 0.9 & GC/MS & Leaves and stems & {$[60]$} \\
\hline Hexadecadienoic acid (\%) & 0.5 & GC & Leaves & {$[61]$} \\
\hline Hexadecatrienoic acid (\%) & 1.3 & GC & Leaves & {$[61]$} \\
\hline Linolenic acid (\%) & $0.4-43.7$ & GC and GC/MS & Leaves and stems & {$[60,61]$} \\
\hline Linoleic acid (\%) & $0.3-63.4$ & GC, GC/MS, and HPLC & Kernel oil, leaves, and stems & {$[16,60,61]$} \\
\hline
\end{tabular}


TABLE 5: Continued.

\begin{tabular}{|c|c|c|c|c|}
\hline Compound & Value & Method of compound analysis & Plant part & References \\
\hline $\boldsymbol{\alpha}$-Linoleic acid (\%) & $0.4-0.7$ & GC/MS, HPLC, and GC & Kernel oil & [16] \\
\hline Myristic acid (\%) & $0.9-2.1$ & GC/MS, HPLC, and GC & Kernel oil and leaves & {$[16,61]$} \\
\hline Nonanedioic acid (\%) & 0.1 & GC/MS & Leaves and stems & {$[60]$} \\
\hline Nonadecanoic acid (\%) & 0.6 & GC/MS & Leaves and stems & {$[60]$} \\
\hline Oleic acid (\%) & $3.8-10.5$ & GC, GC/MS, and HPLC & Kernel oil and leaves & {$[16,61]$} \\
\hline Palmitic acid (\%) & $9.7-20.9$ & GC, GC/MS, HPLC, and NMR & Kernel oil, leaves, and stem bark & {$[16,60,61]$} \\
\hline Palmitoleic acid (\%) & 1.0 & GC & Leaves & {$[61]$} \\
\hline Pentadecanoic acid (\%) & 0.1 & GC/MS & Leaves and stems & {$[60]$} \\
\hline Pentacosanoic acid (\%) & 0.2 & GC/MS & Leaves and stems & {$[60]$} \\
\hline Stearic acid (\%) & $5.1-9.4$ & GC, GC/MS, and HPLC & Kernel oil and leaves & {$[16,61]$} \\
\hline Tetracosanoic acid (\%) & 1.6 & $\mathrm{GC} / \mathrm{MS}$ & Leaves and stems & {$[60]$} \\
\hline Tricosanoic acid (\%) & 1.0 & GC/MS & Leaves and stems & {$[60]$} \\
\hline trans-Hexadecenoic acid (\%) & 1.7 & GC & Leaves & {$[61]$} \\
\hline \multicolumn{5}{|l|}{ Sterols } \\
\hline Campesterol (\%) & 22.7 & GC/MS & Kernel oil & {$[16]$} \\
\hline $\boldsymbol{\beta}$-Sitosterol (\%) & 45.2 & GC/MS and NMR & Kernel oil, leaves, and stem bark & {$[16,60]$} \\
\hline $\boldsymbol{\beta}$-Sitosterol acetate & - & NMR & Leaves and stem bark & {$[60]$} \\
\hline $\boldsymbol{\beta}$-Sitosterol-5- $\boldsymbol{\beta}$-O-glucosapranoside & - & NMR & Leaves and stem bark & {$[60]$} \\
\hline$\Delta$-5-avenasterol $(\%)$ & 1.4 & GC/MS & Kernel oil & {$[16]$} \\
\hline Lanosterin $(\%)$ & 5.6 & GC/MS & Kernel oil & {$[16]$} \\
\hline Cycloartenol (\%) & 4.3 & GC/MS & Kernel oil & {$[16]$} \\
\hline (+)-24-Dammarene-3 $\beta$-20S-diol (\%) & 0.7 & $\mathrm{GC} / \mathrm{MS}$ & Kernel oil & {$[16]$} \\
\hline Stigmasterol (\%) & 20.1 & GC/MS and NMR & Kernel oil, leaves, and stem bark & {$[16,60]$} \\
\hline
\end{tabular}

crude fruit, leaf and seed extracts of $V$. madagascariensis using DPPH (1, 1-Diphenyl-2-picrylhydrazyl) free radical scavenging, hypochlorus acid ( $\mathrm{HOCl}$ ) scavenging, ferric reducing antioxidant power (FRAP), hydroxyl ( $\mathrm{OH})$ radical scavenging or deoxyribose, nitric oxide radical (NO) scavenging and iron chelating property assays (Table 6). The methanol leaf, unripe and ripe fruit extracts exhibited antioxidant properties with $\mathrm{IC}_{50}$ values stretching from $9.0 \mu \mathrm{g} / \mathrm{mL}$ to $48.5 \mu \mathrm{g} / \mathrm{mL}$ which was comparable to ascorbic acid with $\mathrm{IC}_{50}$ value of $0.001 \mu \mathrm{g} / \mathrm{mL}$. All the extracts exhibited activities in the reduction of $\mathrm{Fe}^{4+}$ to $\mathrm{Fe}^{2+}$, confirming antioxidant properties with leaf methanol being the most active and seed decoction being the least active. The methanol unripe fruit extract exhibited the highest $\mathrm{HOCl}$ scavenging properties with $\mathrm{IC}_{50}$ value of $223.0 \mu \mathrm{g} / \mathrm{mL}$ which was comparable to that of ascorbic acid, the control which exhibited $\mathrm{IC}_{50}$ value of $46.0 \mu \mathrm{g} / \mathrm{mL}$. The methanol leaf, unripe and ripe fruit extracts exhibited $\mathrm{OH}$ scavenging properties with $\mathrm{IC}_{50}$ values stretching from $0.1 \mu \mathrm{g} / \mathrm{mL}$ to $0.3 \mu \mathrm{g} / \mathrm{mL}$ which were lower than that of $\alpha$-tocopherol, the control which exhibited $\mathrm{IC}_{50}$ value of $0.5 \mu \mathrm{g} / \mathrm{mL}$. The leaf and unripe fruit crude extracts as well as methanolic leaf, ripe and unripe fruit extracts exhibited NO scavenging properties with $\mathrm{IC}_{50}$ values stretching from $43.2 \mu \mathrm{g} / \mathrm{mL}$ to $436.2 \mu \mathrm{g} / \mathrm{mL}$ which were lower than that of ascorbic acid, the control which exhibited $\mathrm{IC}_{50}$ value of $546.5 \mu \mathrm{g} / \mathrm{mL}$. All the extracts exhibited considerable iron chelating properties with $\mathrm{IC}_{50}$ values stretching from $0.0009 \mu \mathrm{g} / \mathrm{mL}$ to $2.5 \mu \mathrm{g} / \mathrm{mL}$ which were comparable to the positive control EDTA which exhibited $\mathrm{IC}_{50}$ value of $0.001 \mu \mathrm{g} / \mathrm{mL}$ [13]. Mustafa et al. [17] assessed antioxidant properties of bark, leaf and seed extracts of $V$. madagascariensis using DPPH radical scavenging assay and oxygen radical absorbance capacity (Table 6). The DPPH assay revealed activities of leaf, seed and bark extracts with $\mathrm{IC}_{50}$ values of $7.8,31.3$ and $62.5 \mu \mathrm{g} / \mathrm{ml}$, respectively, which were comparable to $\mathrm{IC}_{50}$ value of $3.1 \mu \mathrm{g} / \mathrm{ml}$ exhibited by ascorbic acid, the control. The oxygen radical absorbance ability findings revealed that the leaf extract demonstrated higher levels of antioxidant properties of $72.7 \mu \mathrm{M}$ of trolox than the control, quercetin $(5 \mu \mathrm{g} / \mathrm{ml})$ which showed activity of $59.0 \mu \mathrm{M}$ of trolox), while the bark and seed extracts showed activities of $47.1 \mu \mathrm{M}$ of trolox and $44.9 \mu \mathrm{M}$ of trolox, respectively [17]. The documented antioxidant activities of $V$. madagascariensis extracts are probably due to flavonoids, phenolics and proanthocyanidins detected in fruits, leaves and stems of the species $[14,17,60]$.

4.7. Cytotoxicity Activities. Mustafa et al. [17] assessed cytotoxicity properties of the bark, leaf and seed extracts of $V$. madagascariensis using the MTT [3-(4, 5dimethylthiazole-2yl)2, 5-diphenyltetrazolium bromide] assay using human breast carcinoma (MCF-7), non-small cell lung cancer (A549), prostate adenocarcinoma (PC-3), human hepatocellular carcinoma (HepG2), human colon adenocarcinoma (HT-29), normal hepatic (WRL-68) and normal lung fibro blast (WI-38T) cells (Table 6). Test agents induced cell cytotoxicity in a concentration dependent trend with half maximal effective concentration $\left(\mathrm{EC}_{50}\right)$ values stretching from $22.8 \mu \mathrm{g} / \mathrm{mL}$ to $64.7 \mu \mathrm{g} / \mathrm{mL}$ [17]. These findings corroborate the traditional use of $V$. madagascariensis as herbal concoction for tumour in Sudan [59].

4.8. Antimalarial and Antiplasmodial Activities. Muthaura et al. [55] assessed in vivo antimalarial properties of water and methanol stem bark of $V$. madagascariensis against 
<smiles>CCCCCCCCCCCCCCCCCC</smiles>

Cetyl alcohol<smiles>CCOC(=O)C12CC(O)C(OC(=O)/C=C/c3ccc(O)c(O)c3)C(O)C(OC(CO)C(O)C1O)C(O)C2O</smiles>

Ethyl-1-O-glucosyl-4-O-(E) caffeoyl quinate<smiles></smiles>

Kaempferol-3-O-rhamnoside,7-O-rutinoside<smiles>O=c1ccc2cc(O)c(O)cc2o1</smiles>

Esculetin

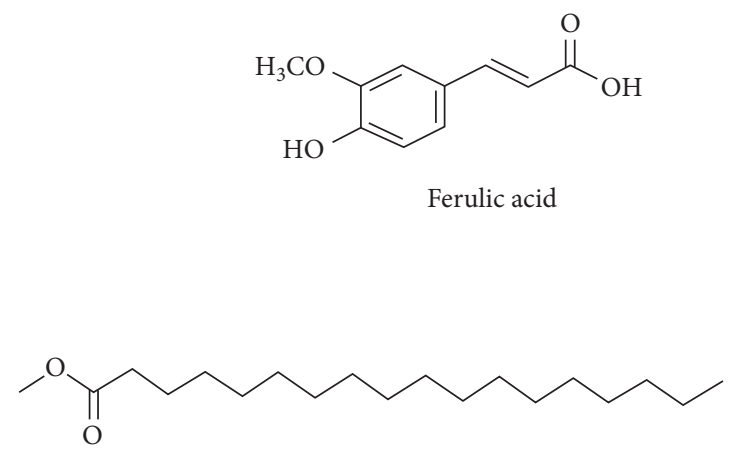

Methyl stearate<smiles>CCCCCCCCCCCCCCCC(=O)O</smiles>

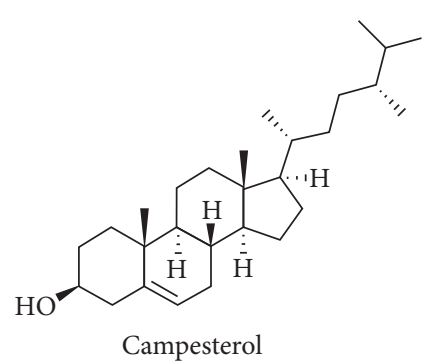

FIgURE 3: Phytochemical structures of representative phytochemical compounds isolated from Vangueria madagascariensis.

Plasmodium berghei strain ANKA using a four-day suppressive assay with chloroquine as positive control. The in vivo studies showed weak activities with chemo-suppression of parasitaemia in Plasmodium berghei infected mice of $26.0 \%$ to $39.0 \%$ which was much lower than $99.9 \%$ exhibited by chloroquine [55]. Similarly, Muthaura et al. [55] assessed antiplasmodial properties of water and methanol stem bark of $V$. madagascariensis against chloroquine sensitive (D6) and resistant (W2) Plasmodium falciparum clones using the $\left[\mathrm{G}-{ }^{3} \mathrm{H}\right]$ hypoxanthine incorporation assay with artemisinin and chloroquine as positive controls (Table 6). The methanol extracts exhibited moderate and weak activities with $\mathrm{IC}_{50}$ values of $13.4 \mu \mathrm{g} / \mathrm{mL}$ and $34.0 \mu \mathrm{g} / \mathrm{mL}$ against D6 and W2 strains, respectively. These results were higher than $\mathrm{IC}_{50}$ values demonstrated by the reference drugs artemisinin $(D 6=0.9 \mathrm{ng} / \mathrm{mL}, W 2=3.4 \mathrm{ng} / \mathrm{mL})$ and chloroquine $(D 6=$ $9.0 \mathrm{ng} / \mathrm{mL}, W 2=31.3 \mathrm{ng} / \mathrm{mL}$ ) [55]. In another study, Muthaura et al. [56] assessed antiplasmodial properties of water and methanol stem bark of $V$. madagascariensis against chloroquine sensitive (D6) and resistant (W2) Plasmodium falciparum clones using the $\left(\mathrm{G}^{-}{ }^{3} \mathrm{H}\right)$ hypoxanthine incorporation assay with artemisinin and chloroquine as positive controls (Table 6). The methanol extracts demonstrated moderate and weak activities with $\mathrm{IC}_{50}$ values of $13.3 \mu \mathrm{g} / \mathrm{mL}$ and $33.9 \mu \mathrm{g} / \mathrm{mL}$ against D6 and W2 strains, respectively. These results were higher than $\mathrm{IC}_{50}$ values demonstrated by the reference drugs artemisinin $(D 6=$ $0.9 \mathrm{ng} / \mathrm{mL}, W 2=3.4 \mathrm{ng} / \mathrm{mL})$ and chloroquine $(D 6=9.0 \mathrm{ng} / \mathrm{mL}$,
$W 2=31.3 \mathrm{ng} / \mathrm{mL}$ ) [56]. Therefore, $V$. madagascariensis extracts showed promising antimalarial and antiplasmodial activities and these findings corroborate the traditional usage of the bark, roots and stem bark of the species as remedies against malaria in Kenya and Tanzania [8, 45, 51, 53-57].

4.8. Toxicity Activities. Bishay et al. [60] evaluated oral acute toxicity of bark and leaf n-hexane, chloroform, ethyl acetate extracts of $V$. madagascariensis by administering doses of $10 \mathrm{mg} / \mathrm{kg}, 100 \mathrm{mg} / \mathrm{kg}$ and $1000 \mathrm{mg} / \mathrm{kg}$ i.p. to male albino rats (Table 6). The treated animals were monitored for $24 \mathrm{hrs}$ for symptoms of toxicity such as writhing, loss of motor coordination, irritability, hypothermia, sedation followed by deep sleep and finally death. The median lethal dose $\left(\mathrm{LD}_{50}\right)$ values of $3.8 \mathrm{~g} / \mathrm{kg}$ for both leaf and stem-bark extracts appear to suggest that the extracts of the species are safe to use as herbal medicines [60]. Muthaura et al. [55] assessed the acute, subacute and chronic toxicity of $V$. madagascariensis stem bark extracts by oral administration in female Swiss mice. The behaviour of mice was observed for 1 hour, intermittently for 4 hours, 24 hours and 14 days noting for any signs of toxicity and the latency of death. The extracts did not cause any mortality or signs of toxicity at any dose level up to the highest dose tested of $5000 \mathrm{mg} / \mathrm{kg}$ [55]. Since $V$. madagascariensis is widely utilized as both food and herbal medicine, there is need to ascertain toxicological properties of the species using different plant parts against several cell 
TABLE 6: Summary of biological properties of Vangueria madagascariensis extracts.

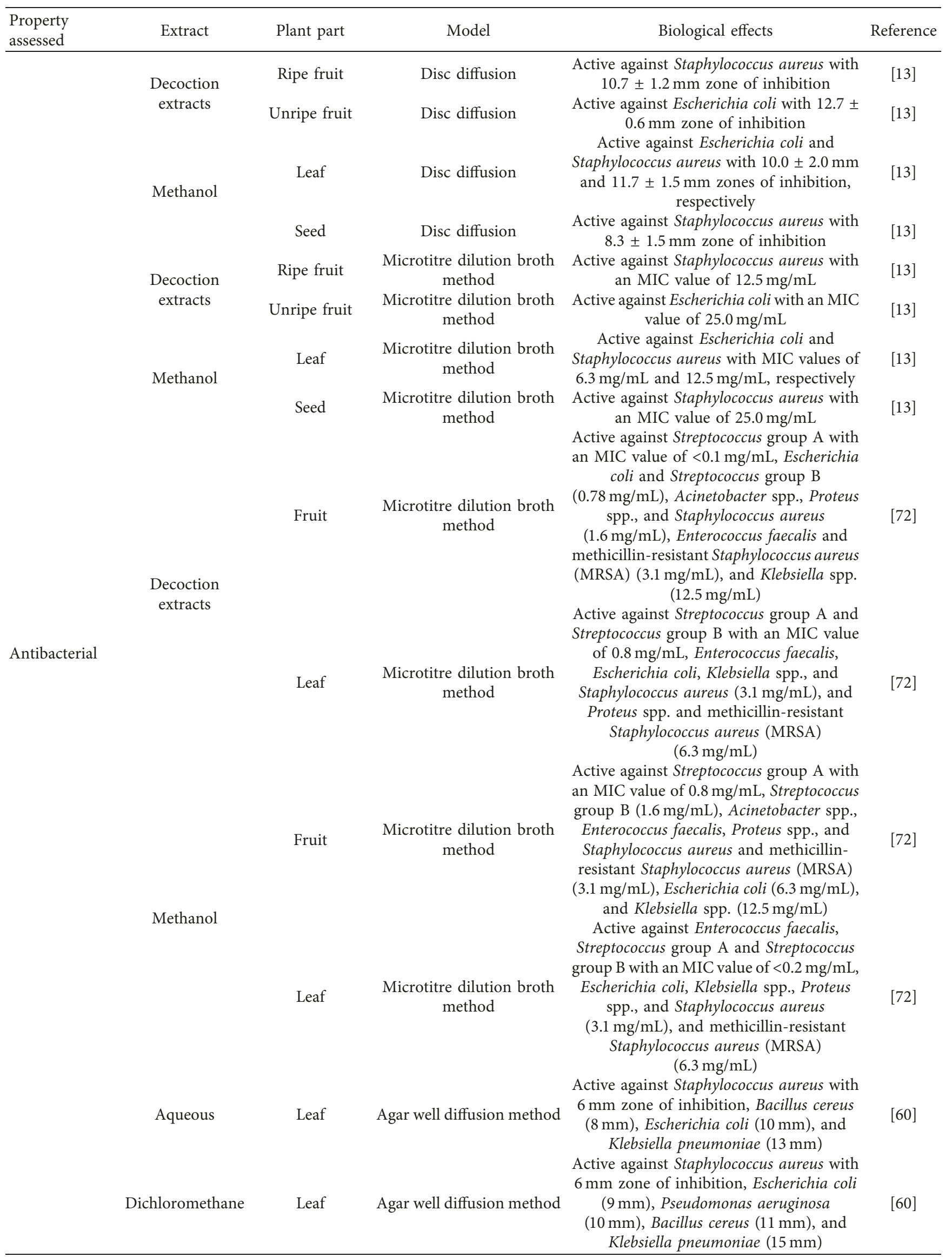


TABle 6: Continued.

\begin{tabular}{|c|c|c|c|c|c|}
\hline $\begin{array}{l}\text { Property } \\
\text { assessed }\end{array}$ & Extract & Plant part & Model & Biological effects & Reference \\
\hline & Ethanol & Leaf & Agar well diffusion method & $\begin{array}{c}\text { Active against Staphylococcus aureus with } \\
4 \mathrm{~mm} \text { zone of inhibition, Micrococcus } \\
\text { luteus }(7 \mathrm{~mm}), \text { Bacillus cereus }(8 \mathrm{~mm}), \\
\text { Escherichia coli }(10 \mathrm{~mm}), \text { Pseudomonas } \\
\text { aeruginosa }(11 \mathrm{~mm}), \text { and Klebsiella } \\
\text { pneumoniae }(17 \mathrm{~mm})\end{array}$ & {$[60]$} \\
\hline & n-Butanol & Leaf & Agar well diffusion method & $\begin{array}{c}\text { Active against Staphylococcus aureus with } \\
5 \mathrm{~mm} \text { zone of inhibition, Escherichia coli } \\
(10 \mathrm{~mm}) \text {, and Klebsiella pneumoniae } \\
(14 \mathrm{~mm})\end{array}$ & {$[60]$} \\
\hline & $n$-Hexane & Leaf & Agar well diffusion method & $\begin{array}{c}\text { Active against Staphylococcus aureus with } \\
6 \mathrm{~mm} \text { zone of inhibition, Micrococcus } \\
\text { luteus }(7 \mathrm{~mm}), \text { Bacillus cereus }(8 \mathrm{~mm}), \\
\text { Escherichia coli }(9 \mathrm{~mm}) \text {, and Klebsiella } \\
\text { pneumoniae }(12 \mathrm{~mm})\end{array}$ & {$[60]$} \\
\hline & Aqueous & Stem bark & Agar well diffusion method & $\begin{array}{c}\text { Active against Micrococcus luteus with } \\
8 \mathrm{~mm} \text { zone of inhibition, Bacillus cereus } \\
\text { with Klebsiella pneumoniae }(9 \mathrm{~mm}) \text {, } \\
\text { Pseudomonas aeruginosa }(10 \mathrm{~mm}) \text {, and } \\
\text { Escherichia coli }(11 \mathrm{~mm})\end{array}$ & {$[60]$} \\
\hline & Dichloromethane & Stem bark & Agar well diffusion method & $\begin{array}{c}\text { Active against Micrococcus luteus with } \\
8 \mathrm{~mm} \text { zone of inhibition, Pseudomonas } \\
\text { aeruginosa }(9 \mathrm{~mm}), \text { Escherichia coli and } \\
\text { Staphylococcus aureus }(10 \mathrm{~mm}), \text { Bacillus } \\
\text { cereus }(12 \mathrm{~mm}) \text {, and Klebsiella pneumoniae } \\
\text { (13 } \mathrm{mm})\end{array}$ & {$[60]$} \\
\hline & Ethanol & Stem bark & Agar well diffusion method & $\begin{array}{c}\text { Active against Micrococcus luteus with } \\
8 \mathrm{~mm} \text { zone of inhibition, Escherichia coli } \\
(10 \mathrm{~mm}), \text { Bacillus cereus and Pseudomonas } \\
\text { aeruginosa }(11 \mathrm{~mm}) \text {, Staphylococcus aureus } \\
(14 \mathrm{~mm}) \text {, and Klebsiella pneumoniae } \\
(15 \mathrm{~mm})\end{array}$ & {$[60]$} \\
\hline & $n$-Hexane & Stem bark & Agar well diffusion method & $\begin{array}{c}\text { Active against Staphylococcus aureus with } \\
9 \mathrm{~mm} \text { zone of inhibition, Bacillus cereus } \\
(10 \mathrm{~mm}) \text {, and Klebsiella pneumoniae } \\
(12 \mathrm{~mm})\end{array}$ & {$[60]$} \\
\hline & Aqueous & Leaf & Agar well diffusion method & $\begin{array}{c}\text { Active against Escherichia coli with an MIC } \\
\text { value of } 15 \mu \mathrm{g} / \mathrm{ml} \text {, Klebsiella pneumoniae } \\
(30 \mu \mathrm{g} / \mathrm{ml}) \text {, Staphylococcus aureus } \\
(40 \mu \mathrm{g} / \mathrm{ml}) \text {, and Bacillus cereus }(75 \mu \mathrm{g} / \mathrm{ml})\end{array}$ & {$[60]$} \\
\hline & Dichloromethane & Leaf & Agar well diffusion method & $\begin{array}{l}\text { Active against Klebsiella pneumoniae with } \\
\text { an MIC value of } 20 \mu \mathrm{g} / \mathrm{ml}, \text { Escherichia coli } \\
\text { and Staphylococcus aureus }(25 \mu \mathrm{g} / \mathrm{ml}) \text {, } \\
\text { Bacillus cereus }(35 \mu \mathrm{g} / \mathrm{ml}) \text {, and } \\
\text { Pseudomonas aeruginosa }(50 \mu \mathrm{g} / \mathrm{ml})\end{array}$ & {$[60]$} \\
\hline & Ethanol & Leaf & Agar well diffusion method & $\begin{array}{c}\text { Active against Klebsiella pneumoniae with } \\
\text { an MIC value of } 15 \mu \mathrm{g} / \mathrm{ml} \text {, Staphylococcus } \\
\text { aureus }(40 \mu \mathrm{g} / \mathrm{ml}), \text { Bacillus cereus and } \\
\text { Escherichia coli ( } 50 \mu \mathrm{g} / \mathrm{ml}) \text {, and } \\
\text { Micrococcus luteus and Pseudomonas } \\
\text { aeruginosa }(55 \mu \mathrm{g} / \mathrm{ml})\end{array}$ & {$[60]$} \\
\hline & $n$-Butanol & Leaf & Agar well diffusion method & $\begin{array}{c}\text { Active against Klebsiella pneumoniae with } \\
\text { an MIC value of } 25 \mu \mathrm{g} / \mathrm{ml} \text {, Staphylococcus } \\
\text { aureus }(36 \mu \mathrm{g} / \mathrm{ml}) \text {, and Escherichia coli } \\
(75 \mu \mathrm{g} / \mathrm{ml})\end{array}$ & {$[60]$} \\
\hline & $n$-Hexane & Leaf & Agar well diffusion method & $\begin{array}{c}\text { Active against Bacillus cereus with an MIC } \\
\text { value of } 6.3 \mu \mathrm{g} / \mathrm{ml} \text {, Klebsiella pneumoniae } \\
(25 \mu \mathrm{g} / \mathrm{ml}) \text {, Staphylococcus aureus } \\
(37 \mu \mathrm{g} / \mathrm{ml}), \text { Escherichia coli }(60 \mu \mathrm{g} / \mathrm{ml}) \text {, and } \\
\text { Micrococcus luteus }(75 \mu \mathrm{g} / \mathrm{ml})\end{array}$ & {$[60]$} \\
\hline & Aqueous & Stem bark & Agar well diffusion method & $\begin{array}{l}\text { Active against Pseudomonas aeruginosa } \\
\text { with an MIC value of } 25 \mu \mathrm{g} / \mathrm{ml} \text {, Escherichia } \\
\text { coli and Klebsiella pneumoniae }(35 \mu \mathrm{g} / \mathrm{ml}) \text {, }\end{array}$ & {$[60]$} \\
\hline
\end{tabular}


TABle 6: Continued.

\begin{tabular}{|c|c|c|c|c|c|}
\hline $\begin{array}{l}\text { Property } \\
\text { assessed }\end{array}$ & Extract & Plant part & Model & Biological effects & Reference \\
\hline & Dichloromethane & Stem bark & Agar well diffusion method & $\begin{array}{l}\text { and Bacillus cereus and Micrococcus luteus } \\
\qquad(75 \mu \mathrm{g} / \mathrm{ml}) \\
\text { Active against Escherichia coli with an MIC } \\
\text { value of } 20 \mu \mathrm{g} / \mathrm{ml} \text {, Klebsiella pneumoniae } \\
(24 \mu \mathrm{g} / \mathrm{ml}), \text { Pseudomonas aeruginosa } \\
(25 \mu \mathrm{g} / \mathrm{ml}), \text { Staphylococcus aureus } \\
(33 \mu \mathrm{g} / \mathrm{ml}), \text { Micrococcus luteus }(50 \mu \mathrm{g} / \mathrm{ml}) \text {, } \\
\text { and Bacillus cereus }(55 \mu \mathrm{g} / \mathrm{ml})\end{array}$ & {$[60]$} \\
\hline & Ethanol & Stem bark & Agar well diffusion method & $\begin{array}{c}\text { Active against Klebsiella pneumoniae and } \\
\text { Staphylococcus aureus with an MIC value } \\
\text { of } 20 \mu \mathrm{g} / \mathrm{ml} \text {, Escherichia coli, Micrococcus } \\
\text { luteus, and Pseudomonas aeruginosa } \\
(25 \mu \mathrm{g} / \mathrm{ml}) \text {, and Bacillus cereus }(50 \mu \mathrm{g} / \mathrm{ml})\end{array}$ & {$[60]$} \\
\hline & $n$-Hexane & Stem bark & Agar well diffusion method & $\begin{array}{c}\text { Active against Klebsiella pneumoniae with } \\
\text { an MIC value of } 24 \mu \mathrm{g} / \mathrm{ml} \text {, Staphylococcus } \\
\text { aureus }(35 \mu \mathrm{g} / \mathrm{ml}) \text {, and Bacillus cereus } \\
(65 \mu \mathrm{g} / \mathrm{ml})\end{array}$ & {$[60]$} \\
\hline \multirow{6}{*}{ Antidiabetic } & \multirow[t]{2}{*}{ Decoction extract } & $\begin{array}{l}\text { Fruit, leaf, and } \\
\text { seed }\end{array}$ & $\alpha$-Amylase & $\begin{array}{c}\text { Decoctions active with } \mathrm{IC}_{50} \text { values of } \\
1.1 \mathrm{mg} / \mathrm{mL} \text { (leaf), } 5.3 \mathrm{mg} / \mathrm{mL} \text { (unripe } \\
\text { fruit), } 6.8 \mathrm{mg} / \mathrm{mL} \text { (seed), and } 29.6 \mathrm{mg} / \mathrm{mL} \\
\text { (ripe fruit) }\end{array}$ & {$[13]$} \\
\hline & & Fruit and leaf & $\alpha$-Glucosidase & $\begin{array}{l}\text { Decoctions active with } \mathrm{IC}_{50} \text { values of } \\
0.5 \mathrm{mg} / \mathrm{mL} \text { (unripe fruit), } 0.6 \mathrm{mg} / \mathrm{mL} \\
\text { (leaf), and } 15.7 \mathrm{mg} / \mathrm{mL} \text { (ripe fruit) }\end{array}$ & {$[13]$} \\
\hline & \multirow{2}{*}{ Methanol } & $\begin{array}{l}\text { Fruit, leaf, and } \\
\text { seed }\end{array}$ & $\alpha$-Amylase & $\begin{array}{c}\text { Extracts active with } \mathrm{IC}_{50} \text { values of } \\
1.2 \mathrm{mg} / \mathrm{mL} \text { (unripe fruit), } 1.7 \mathrm{mg} / \mathrm{mL} \\
\text { (leaf), } 3.8 \mathrm{mg} / \mathrm{mL} \text { (seed), and } 7.7 \mathrm{mg} / \mathrm{mL} \\
\text { (ripe fruit) }\end{array}$ & {$[13]$} \\
\hline & & $\begin{array}{l}\text { Fruit, leaf, and } \\
\text { seed }\end{array}$ & $\alpha$-Glucosidase & $\begin{array}{l}\text { Extracts active with } \mathrm{IC}_{50} \text { values of } \\
0.4 \mathrm{mg} / \mathrm{mL} \text { (unripe fruit), } 3.3 \mathrm{mg} / \mathrm{mL} \text { (ripe } \\
\text { fruit), } 6.2 \mathrm{mg} / \mathrm{mL} \text { (leaf), and } 46.3 \mathrm{mg} / \mathrm{mL} \\
\text { (seed) }\end{array}$ & {$[13]$} \\
\hline & \multirow{2}{*}{ Ethanol } & Bark & $\alpha$-Amylase & $\begin{array}{c}\text { Extracts active with } \mathrm{IC}_{50} \text { values of } \\
11.6 \mu \mathrm{g} / \mathrm{mL}\end{array}$ & {$[73]$} \\
\hline & & Bark & $\alpha$-Glucosidase & $\begin{array}{l}\text { Extracts active with } \mathrm{IC}_{50} \text { values of } \\
1.8 \mu \mathrm{g} / \mathrm{mL}\end{array}$ & {$[73]$} \\
\hline \multirow{5}{*}{ Antifungal } & \multirow{4}{*}{ Several extracts } & Leaf & Agar well diffusion method & $\begin{array}{l}n \text {-Butanol and } n \text {-hexane active against } \\
\text { Candida albicans with } 9 \mathrm{~mm} \text { zone of } \\
\text { inhibition, ethanol }(10 \mathrm{~mm}) \text {, aqueous } \\
(14 \mathrm{~mm}) \text {, and dichloromethane }(20 \mathrm{~mm})\end{array}$ & {$[60]$} \\
\hline & & Stem bark & Agar well diffusion method & $\begin{array}{l}\text { Aqueous and } n \text {-hexane active against } \\
\text { Candida albicans with } 14 \mathrm{~mm} \text { zone of } \\
\text { inhibition, ethanol }(18 \mathrm{~mm}) \text {, and } \\
\text { dichloromethane }(21 \mathrm{~mm})\end{array}$ & {$[60]$} \\
\hline & & Leaf & Agar well diffusion method & $\begin{array}{l}\text { Ethanol extract active against Candida } \\
\text { albicans with an MIC value of } 13 \mu \mathrm{g} / \mathrm{ml} \text {, } \\
\text { dichloromethane }(14 \mu \mathrm{g} / \mathrm{ml}), \text { aqueous } \\
(18 \mu \mathrm{g} / \mathrm{ml}), n \text {-butanol }(30 \mu \mathrm{g} / \mathrm{ml}) \text {, and } n \text { - } \\
\text { hexane }(35 \mu \mathrm{g} / \mathrm{ml})\end{array}$ & {$[60]$} \\
\hline & & Stem bark & Agar well diffusion method & $\begin{array}{l}\text { Ethanol extract active against Candida } \\
\text { albicans with an MIC value of } 15 \mu \mathrm{g} / \mathrm{ml} \text {, } \\
\text { dichloromethane }(18 \mu \mathrm{g} / \mathrm{ml}), n \text {-hexane } \\
(30 \mu \mathrm{g} / \mathrm{ml}), \text { and aqueous }(55 \mu \mathrm{g} / \mathrm{ml})\end{array}$ & {$[60]$} \\
\hline & Chloroform & Fruit & Agar well diffusion method & $\begin{array}{l}\text { Chloroform extract active against } \\
\text { Aspergillus niger and Candida albicans } \\
\text { with } 15 \mathrm{~mm} \text { and } 14 \mathrm{~mm} \text { zones of } \\
\text { inhibition, respectively }\end{array}$ & {$[74]$} \\
\hline \multirow[t]{2}{*}{ Antioxidant } & Decoction & $\begin{array}{l}\text { Fruit, leaf, and } \\
\text { seed }\end{array}$ & $\mathrm{DPPH}$ & $\begin{array}{c}\text { Extracts active with } \mathrm{IC}_{50} \text { values of } \\
132.8 \mu \mathrm{g} / \mathrm{mL} \text { (leaf), } 602.5 \mu \mathrm{g} / \mathrm{mL} \text { (ripe } \\
\text { fruit), and } 612.5 \mu \mathrm{g} / \mathrm{mL} \text { (unripe fruit and } \\
\text { seed) }\end{array}$ & {$[13]$} \\
\hline & Methanol & & DPPH & & {$[13]$} \\
\hline
\end{tabular}


TABle 6: Continued.

\begin{tabular}{|c|c|c|c|c|c|}
\hline $\begin{array}{l}\text { Property } \\
\text { assessed }\end{array}$ & Extract & Plant part & Model & Biological effects & Reference \\
\hline & & $\begin{array}{c}\text { Fruit, leaf, and } \\
\text { seed }\end{array}$ & & $\begin{array}{c}\text { Extracts active with } \mathrm{IC}_{50} \text { values of } \\
9.0 \mu \mathrm{g} / \mathrm{mL} \text { (leaf), } 10.0 \mu \mathrm{g} / \mathrm{mL} \text { (unripe fruit), } \\
48.5 \mu \mathrm{g} / \mathrm{mL} \text { (ripe fruit), and } 105.9 \mu \mathrm{g} / \mathrm{mL} \\
\text { (seed) }\end{array}$ & \\
\hline & Decoction & $\begin{array}{c}\text { Fruit, leaf, and } \\
\text { seed }\end{array}$ & FRAP & $\begin{array}{l}\text { Exhibited antioxidant activity with } 319.2 \\
\text { (seed), } 322.9 \text { (ripe fruit), } 330.8 \text { (unripe } \\
\text { fruit), and } 350.4 \text { (leaf) mM Trolox } \\
\text { equivalent (TE)/g fresh weight }\end{array}$ & [13] \\
\hline & Methanol & $\begin{array}{l}\text { Fruit, leaf, and } \\
\text { seed }\end{array}$ & FRAP & $\begin{array}{l}\text { Exhibited antioxidant activity with } 346.7 \\
\text { (seed), } 357.1 \text { (ripe fruit), } 361.3 \text { (unripe } \\
\text { fruit), and } 372.5 \text { (leaf) mM Trolox } \\
\text { equivalent (TE)/g fresh weight }\end{array}$ & [13] \\
\hline & $\begin{array}{l}\text { Decoction } \\
\text { extracts }\end{array}$ & $\begin{array}{c}\text { Fruit, leaf, and } \\
\text { seed }\end{array}$ & $\mathrm{HOCl}$ & $\begin{array}{c}\text { Active with IC50 values of } 235.6 \mu \mathrm{g} / \mathrm{mL} \\
\text { (leaf), } 275.3 \mu \mathrm{g} / \mathrm{mL} \text { (unripe fruit), } \\
982.4 \mu \mathrm{g} / \mathrm{mL} \text { (ripe fruit), and } 6656.4 \mu \mathrm{g} / \mathrm{mL} \\
\text { (seed) }\end{array}$ & {$[13]$} \\
\hline & Methanol & $\begin{array}{l}\text { Fruit, leaf, and } \\
\text { seed }\end{array}$ & $\mathrm{HOCl}$ & $\begin{array}{c}\text { Active with } \mathrm{IC}_{50} \text { values of } 223.0 \mu \mathrm{g} / \mathrm{mL} \\
\text { (unripe fruit), } 382.1 \mu \mathrm{g} / \mathrm{mL} \text { (leaf), } \\
418.9 \mu \mathrm{g} / \mathrm{mL} \text { (ripe fruit), and } 941.5 \mu \mathrm{g} / \mathrm{mL} \\
\text { (seed) }\end{array}$ & [13] \\
\hline & $\begin{array}{l}\text { Decoction } \\
\text { extracts }\end{array}$ & $\begin{array}{c}\text { Fruit, leaf, and } \\
\text { seed }\end{array}$ & $\mathrm{OH}$ & $\begin{array}{c}\text { Active with } \mathrm{IC}_{50} \text { values of } 157.2 \mu \mathrm{g} / \mathrm{mL} \\
\text { (unripe fruit), } 261.0 \mu \mathrm{g} / \mathrm{mL} \text { (ripe fruit), } \\
289.0 \mu \mathrm{g} / \mathrm{mL} \text { (leaf), and } 803.8 \mu \mathrm{g} / \mathrm{mL} \\
\text { (seed) }\end{array}$ & [13] \\
\hline & Methanol & $\begin{array}{c}\text { Fruit, leaf, and } \\
\text { seed }\end{array}$ & $\mathrm{OH}$ & $\begin{array}{l}\text { Active with } \mathrm{IC}_{50} \text { values of } 0.1 \mu \mathrm{g} / \mathrm{mL} \text { (leaf), } \\
0.3 \mu \mathrm{g} / \mathrm{mL} \text { (ripe and unripe fruits), and } \\
22.4 \mu \mathrm{g} / \mathrm{mL} \text { (seed) }\end{array}$ & [13] \\
\hline \multirow{6}{*}{ Antioxidant } & $\begin{array}{l}\text { Decoction } \\
\text { extracts }\end{array}$ & $\begin{array}{c}\text { Fruit, leaf, and } \\
\text { seed }\end{array}$ & NO & $\begin{array}{c}\text { Active with } \mathrm{IC}_{50} \text { values of } 241.2 \mu \mathrm{g} / \mathrm{mL} \\
\text { (leaf), } 436.2 \mu \mathrm{g} / \mathrm{mL} \text { (unripe fruit) } \\
2367.4 \mu \mathrm{g} / \mathrm{mL} \text { (ripe fruit), and } \\
6092.4 \mu \mathrm{g} / \mathrm{mL} \text { (seed) }\end{array}$ & {$[13]$} \\
\hline & Methanol & $\begin{array}{l}\text { Fruit, leaf, and } \\
\text { seed }\end{array}$ & NO & $\begin{array}{c}\text { Active with } \mathrm{IC}_{50} \text { values of } 43.2 \mu \mathrm{g} / \mathrm{mL} \\
\text { (leaf), } 91.4 \mu \mathrm{g} / \mathrm{mL} \text { (unripe fruit), } \\
219.1 \mu \mathrm{g} / \mathrm{mL} \text { (ripe fruit), and } 1103.2 \mu \mathrm{g} / \mathrm{mL} \\
\text { (seed) }\end{array}$ & [13] \\
\hline & $\begin{array}{l}\text { Decoction } \\
\text { extracts }\end{array}$ & $\begin{array}{c}\text { Fruit, leaf, and } \\
\text { seed }\end{array}$ & Iron chelation & $\begin{array}{l}\text { Active with } \mathrm{IC}_{50} \text { values of } 0.3 \mu \mathrm{g} / \mathrm{mL} \\
\text { (seed), } 0.6 \mu \mathrm{g} / \mathrm{mL} \text { (ripe fruit), } 1.0 \mu \mathrm{g} / \mathrm{mL} \\
\text { (unripe fruit), and } 2.5 \mu \mathrm{g} / \mathrm{mL} \text { (leaf) }\end{array}$ & {$[13]$} \\
\hline & Methanol & $\begin{array}{l}\text { Fruit, leaf, and } \\
\text { seed }\end{array}$ & Iron chelation & $\begin{array}{l}\text { Active with } \mathrm{IC}_{50} \text { values of } 0.0009 \mu \mathrm{g} / \mathrm{mL} \\
\text { (seed), } 0.002 \mu \mathrm{g} / \mathrm{mL} \text { (leaf), } 0.06 \mu \mathrm{g} / \mathrm{mL} \\
\text { (ripe fruit), and } 0.07 \mu \mathrm{g} / \mathrm{mL} \text { (unripe fruit) }\end{array}$ & {$[13]$} \\
\hline & Methanol & $\begin{array}{l}\text { Bark, leaf, and } \\
\text { seed }\end{array}$ & DPPH & $\begin{array}{c}\text { Extracts active with } \mathrm{IC}_{50} \text { values of } \\
7.8 \mu \mathrm{g} / \mathrm{ml} \text { (leaf), } 31.3 \mu \mathrm{g} / \mathrm{ml} \text { (seed), and } \\
62.5 \mu \mathrm{g} / \mathrm{ml} \text { (bark) }\end{array}$ & [17] \\
\hline & Methanol & $\begin{array}{l}\text { Bark, leaf, and } \\
\text { seed }\end{array}$ & ORAC & $\begin{array}{c}\text { Extracts active with } 44.9 \mu \mathrm{M} \text { of Trolox } \\
\text { (seed), } 47.1 \mu \mathrm{M} \text { of Trolox (bark), and } \\
72.7 \mu \mathrm{M} \text { of Trolox (leaf) }\end{array}$ & [17] \\
\hline Antiplasmodial & Methanol & Leaf & G- ${ }^{3} \mathrm{H}$ hypoxanthine & $\begin{array}{c}\text { Active against Plasmodium falciparum } \\
\text { with } \mathrm{IC}_{50} \text { values of } 13.4 \mu \mathrm{g} / \mathrm{ml} \text { and } \\
34.0 \mu \mathrm{g} / \mathrm{ml} \text { against D6 and } \mathrm{W} 2 \text { strains, } \\
\text { respectively }\end{array}$ & {$[55,56]$} \\
\hline Cytotoxicity & Crude extracts & Stem bark & MTT assay & $\begin{array}{c}\text { Extracts active with } \mathrm{EC}_{50} \text { values of } \\
22.8 \mu \mathrm{g} / \mathrm{ml} \text { (MCF-7), } 28.4 \mu \mathrm{g} / \mathrm{ml} \text { (HepG2), } \\
34.4 \mu \mathrm{g} / \mathrm{ml}(\mathrm{PC}-3), 42.5 \mu \mathrm{g} / \mathrm{ml} \text { (A549), } \\
44.5 \mu \mathrm{g} / \mathrm{ml}(\mathrm{WRL}-68), 53.2 \mu \mathrm{g} / \mathrm{ml}(\mathrm{HT}-29) \\
\text { and } 64.7 \mu \mathrm{g} / \mathrm{ml}(\mathrm{WI}-38 \mathrm{~T})\end{array}$ & {$[17]$} \\
\hline Toxicity & Ethanol & $\begin{array}{l}\text { Leaf and stem } \\
\text { bark }\end{array}$ & $\begin{array}{c}\text { In vivo animal toxicity } \\
\text { activities }\end{array}$ & $\begin{array}{l}\text { All extracts appear to be nontoxic with } \\
\mathrm{LD}_{50} \text { values of } 3.8 \mathrm{~g} / \mathrm{kg}\end{array}$ & {$[60]$} \\
\hline
\end{tabular}


lines using both in vitro toxicological assays and in vivo studies.

\section{Conclusion}

Vangueria madagascariensis is an important functional food and source of nutraceutical ingredients in tropical Africa. Significant breakthrough has been made in the last 30 years elucidating the nutritional, phytochemical and pharmacological properties of the species. However, there are still some research gaps regarding correlating the nutritional and phytochemical properties of the species with its food value and medicinal applications. Detailed studies on the phytochemistry, pharmacokinetics, in vivo and clinical research are required. Further research on the antinutritive, enzymatic and molecular effects of $V$. madagascariensis fruits and kernel oil on human health will be needed to motivate further interest in the use of these products as food sources, additives and health promoting products. Given the situation that $V$. madagascariensis is used as herbal medicine in combination with other plant species such as Azadirachta indica, Ipomoea pes-caprae, Jatropha curcas, Sporobolus africanus and Toddalia asiatica, there is need to investigate the possibility of synergetic effects of the combined extracts. Since $V$. madagascariensis is a valuable functional food and nutraceutical plant species in tropical Africa, there is need to establish the toxicity and/or any side effects that can arise when the species and its products are used as functional food and sources of nutraceutical ingredients and/or as herbal medicines.

\section{Conflicts of Interest}

The author declares that there are no conflicts of interest regarding the publication of this paper.

\section{Acknowledgments}

The author would like to express his gratitude to the National Research Foundation (NRF), South Africa, and Govan Mbeki Research and Development Centre (GMRDC), University of Fort Hare, for financial support to conduct this study.

\section{References}

[1] H. Lantz and B. Bremer, "Phylogeny of the complex Vanguerieae (Rubiaceae) genera Fadogia, Rytigynia, and Vangueria with close relatives and a new circumscription of Vangueria," Plant Systematics and Evolution, vol. 253, no. 1-4, pp. 159-183, 2005.

[2] B. Bremer, "A review of molecular phylogenetic studies of Rubiaceae," Annals of the Missouri Botanical Garden, vol. 96, no. 1, pp. 4-26, 2009.

[3] D. M. Bridson, "Rubiaceae," in Flora Zambesiaca, G. V. Pope, Ed., vol. 5, pp. 249-250, Royal Botanic Gardens, Kew, London, UK, 1998.

[4] E. Palmer and P. Pitman, Trees of Southern Africa Covering all Known Indigenous Species in the Republic of South Africa, South West Africa, Botswana, Lesotho and Swaziland, A.A. Balkema, Cape Town, South Africa, 1972.
[5] E. Schmidt, M. Lotter, and W. McCleland, Trees and Shrubs of Mpumalanga and Kruger National Park, Jacana Publishers, Johannesburg, South Africa, 2002.

[6] A. Maroyi, "Nutraceutical and ethnopharmacological properties of Vangueria infausta subsp. infausta," Molecules, vol. 23, no. 5, p. 1089, 2018.

[7] J. C. Roecklein and S. L. Ping, A Profile of Economic Plants, Transaction, Inc- Rutgers, New Jersey, USA, 1987.

[8] C. K. Ruffo, A. Birnie, and B. Tengäs, Edible Wild Plants of Tanzania, RELMA Technical Handbook Series 27, Regional Land Management Unit (RELMA), Nairobi, Kenya, 2002.

[9] J. Pino, R. Marbot, and C. Vázquez, "Volatile components of the fruits of Vangueria madagascariensis J. F. Gmel. from Cuba," Journal of Essential Oil Research, vol. 16, no. 4, pp. 302-304, 2004.

[10] C. Whitefoord, "Recent plant collections from Dominica," Journal of the Arnold Arboretem, vol. 70, no. 1, pp. 143-152, 1989.

[11] P. Hanelt and R. Büttner, Mansfeld's Encyclopedia of Agricultural and Horticultural Crops (Except Ornamentals), Springer, New York, NY, USA, 2001.

[12] C. Orwa, A. Mutua, R. Kindt et al., Vangueria madagascariensis J. F. Gmelin (Rubiaceae). Agroforestree Database: a tree reference and selection guide version 4.0, 2009, http://www. worldagroforestry.org/sites/treedbs/treedatabases.asp.

[13] N. Ramalingum and M. F. Mahomoodally, "Biologic propensities and phytochemical profile of Vangueria madagascariensis J. F. Gmelin (Rubiaceae): an underutilized native medicinal food plant from Africa," BioMed Research International, vol. 2014, Article ID 681073, 15 pages, 2014.

[14] N. Ramalingum and M. F. Mahomoodally, "Vangueria madagascariensis J. F. Gmelin (Rubiaceae): an under-utilised African traditional medicinal food plant with potential application," Journal of Intercultural Ethnopharmacology, vol. 3, no. 1, pp. 45-48, 2014.

[15] A. A. Mariod, M. E. S. Mirghani, and I. Hussein, "Vangueria madagascariensis (Rubiaceae) as new oil source," in Unconventional Oilseeds and Oil Sources, A. A. Mariod, M. E. S. Mirghani, and I. Hussein, Eds., pp. 167-178, Academic Press, London, UK, 2017.

[16] S. E. Mustafa, "The potential of Vangueria madagascariensis as a source for un-conventional oil in Sudan," Agricultural and Biological Sciences Journal, vol. 3, no. 4, pp. 28-32, 2017.

[17] S. E. Mustafa, A. A. Mariod, Y. M. Ahmed et al., "Antioxidant activity and cytotoxicity study of Vangueria madagascariensis leaf, bark and seed cake methanolic extracts," Australian Journal of Basic Applied Sciences, vol. 11, no. 3, pp. 64-70, 2017.

[18] A. Maroyi, "Azanza garckeana fruit tree: phytochemistry, pharmacology, nutritional and primary healthcare applications as herbal medicine," Research Journal of Medicinal Plants, vol. 11, no. 4, pp. 115-123, 2017.

[19] A. Maroyi, "Contribution of Schinziophyton rautanenii to sustainable diets, livelihood needs and environmental sustainability in Southern Africa," Sustainability, vol. 10, no. 3, p. 581, 2018.

[20] G. Hailu, A. Boecker, S. Henson et al., "Consumer valuation of functional foods and nutraceuticals in Canada: a conjoint study using probiotics," Appetite, vol. 52, no. 2, pp. 257-265, 2009.

[21] F. Shahidi, "Nutraceuticals and functional foods: whole versus processed foods," Trends in Food Science and Technology, vol. 20, no. 9, pp. 376-387, 2009. 
[22] C. Wang and S. Li, "Functional foods and nutraceuticals: potential role in human health," in Clinical Aspects of Functional Foods and Nutraceuticals, D. Ghoshi, D. Bagchi, and T. Konishi, Eds., pp. 51-76, CRC Press, London, UK, 2015.

[23] Z. Teklehaimanot, "The role of indigenous fruit trees in sustainable dryland agriculture in Eastern Africa," in Indigenous Fruit Trees in the Tropics: Domestication, Utilization and Commercialization, F. K. Akinnifesi, R. R. B. Leakey, O. C. Ajayi et al., Eds., pp. 204-223, ICRAF, Nairobi, Kenya, 2008.

[24] E. Styger, J. E. M. Rakotoarimanana, R. Rabevohitra et al., "Indigenous fruit trees of Madagascar: potential components of agroforestry systems to improve human nutrition and restore biological diversity," Agroforestry Systems, vol. 46, no. 3, pp. 289-310, 1999.

[25] T. S. Msuya, J. R. Kideghesho, and T. C. E. Mosha, "Availability, preference, and consumption of indigenous forest foods in the eastern arc mountains, Tanzania," Ecology of Food and Nutrition, vol. 49, no. 3, pp. 208-227, 2010.

[26] F. W. Martin, C. W. Campbell, and R. M. Rubertbe, Perennial Edible Fruits of the Tropics: An Inventory, US Department of Agriculture, Agriculture Research Service, Washington D.C., USA, 1987.

[27] N. K. E.-M. Salih and A. H. Ali, "Wild food trees in eastern Nuba mountains, Sudan: use, diversity, and threatening factors," Journal of Agriculture and Rural Development in the Tropics and Subtropics, vol. 115, no. 1, pp. 1-7, 2014.

[28] G. Addis, Z. Asfaw, and Z. Woldu, "Ethnobotany of wild and semi-wild edible plants of Konso ethnic community, South Ethiopia," Ethnobotany Research Applications, vol. 11, pp. 121-141, 2013.

[29] W. Kipkore, B. Wanjohi, H. Rono et al., "A study of the medicinal plants used by the Marakwet community in Kenya," Journal of Ethnobiology and Ethnomedicine, vol. 10, no. 1, p. 24, 2014.

[30] B. Kidane, L. J. G. van der Maesen, T. van Andel et al., "Ethnobotany of wild and semi-wild edible fruit species used by Maale and Ari ethnic communities in southern Ethiopia," Ethnobotany Research Application, vol. 12, pp. 455-471, 2014.

[31] S. Nigam, D. K. Bhatt, and A. Jha, "Different product of mango: the king of fruits," Processed Food Industry, vol. 10, pp. 32-40, 2007.

[32] C. B. Kipkemboi, "Determination of selected essential elements in traditional vegetables, medicinal plants, fruits and conventionally grown vegetables in koibatek, Kenya," MSc dissertation, Kenyatta University, Nairobi, Kenya, 2009.

[33] L. K. Nyanga, T. H. Gadaga, M. J. R. Nout et al., "Nutritive value of masau (Ziziphus mauritiana) fruits from Zambezi Valley in Zimbabwe," Food Chemistry, vol. 138, no. 1, pp. 168-172, 2013.

[34] S. Pareek, "Nutritional composition of jujube fruit," Emirates Journal of Food and Agriculture, vol. 25, no. 6, pp. 463-470, 2013.

[35] R. Ara, M. Motalab, M. N. Uddin et al., "Nutritional evaluation of different mango varieties available in Bangladesh," International Food Research Journal, vol. 21, no. 6, pp. 2169-2174, 2014.

[36] L. M. R. da Silva, E. A. T. de Figueiredo, N. M. P. S. Ricardo et al., "Quantification of bioactive compounds in pulps and by-products of tropical fruits from Brazil," Food Chemistry, vol. 143, pp. 398-404, 2014.

[37] M. A. M. Sajib, M. M. Hoque, S. Yeasmin et al., "Minerals and heavy metals concentration in selected tropical fruits of
Bangladesh," International Food Research Journal, vol. 21, no. 5, pp. 1731-1736, 2014.

[38] B. A. Jama, A. M. Mohamed, and J. Mulatya, "Comparing the "big five": a framework for the sustainable management of indigenous fruit trees in the drylands of east and central Africa," Ecological Indicators, vol. 8, no. 2, pp. 170-179, 2008.

[39] Institute of Medicine, Dietary Reference Intakes for Energy, Carbohydrates, Fiber, Fat, Fatty Acids, Cholesterol, Protein, and Amino Acids, The National Academies Press, Washington, D.C., USA, 2002.

[40] L. P. Sena, D. J. Van Der Jagt, C. Rivera et al., "Analysis of nutritional components of eight famine foods of the Republic of Niger," Plant Foods for Human Nutrition, vol. 52, no. 1, pp. 17-30, 1998.

[41] I. S. E. Bally, "Mangifera indica (mango): Anacardiaceae (cashew family)," in Species Profiles for Pacific Island Agroforestry, C. R. Elevitch, Ed., pp. 1-24, Permanent Agriculture Resources (PAR), Holuoloa, Hawaii, USA, 2006.

[42] C. Vilela, S. A. O. Santos, L. Oliveira et al., "The ripe pulp of Mangifera indica L.: a rich source of phytosterols and other lipophilic phytochemicals," Food Research International, vol. 54, no. 2, pp. 1535-1540, 2013.

[43] A. B. Deshpande, H. G. Chidley, P. S. Oak et al., "Data on changes in the fatty acid composition during fruit development and ripening of three mango cultivars (Alphonso, Pairi and Kent) varying in lactone content," Data in Brief, vol. 9, pp. $480-491,2016$.

[44] FAO/WHO/UNU, Protein and Amino Acid Requirements in Human Nutrition, WHO Press, Geneva, Switzerland, 2007.

[45] S. C. Chhabra, R. L. A. Mahunnah, and E. N. Mshiu, "Plants used in traditional medicine in eastern Tanzania. v. Angiosperms (Passifloraceae to Sapindaceae)," Journal of Ethnopharmacology, vol. 33, no. 1, pp. 143-157, 1991.

[46] D. Tsigemelak, N. Dharani, J. I. Kinyamario et al., "The utilization of medicinal plants by the Masaai community in arid lands of Kajiado County, Kenya," International Journal of Plant, Animal and Environmental Science, vol. 6, no. 3, pp. 151-159, 2016.

[47] A. Gurib-Fakim and T. Brendler, Medicinal and Aromatic Plants of Indian Ocean Islands: Madagascar, Comoros, Seychelles and Mascarenes, Medpharm Scientific Publications, Stuttgart, Germany, 2004.

[48] A. Mootoosamy and M. F. Mahomoodally, "Ethnomedicinal application of native remedies used against diabetes and related complications in Mauritius," Journal of Ethnopharmacology, vol. 151, no. 1, pp. 413-444, 2013.

[49] M. S. Musa, F. E. Abdelrasool, E. A. Elsheikh et al., "Ethnobotanical study of medicinal plants in the Blue Nile state, south-eastern Sudan," Journal of Medicinal Plant Research, vol. 5, no. 17, pp. 4287-4297, 2011.

[50] T. O. Issa, Y. S. Mohamed, S. Yagi et al., "Ethnobotanical investigation on medicinal plants in Algoz area (South Kordofan), Sudan," Journal of Ethnobiology and Ethnomedicine, vol. 14, no. 1, p. 31, 2018.

[51] S. C. Chhabra, F. C. Uiso, and E. N. Mshiu, "Phytochemical screening of Tanzanian medicinal plants. i," Journal of Ethnopharmacology, vol. 11, no. 2, pp. 157-179, 1984.

[52] B. Yemane, G. Medhanie, and R. K. Surender, "Survey of some common medicinal plants used in Eritrean folk medicine," American Journal of Ethnomedicine, vol. 4, no. 2, 2017.

[53] P. E. Glover, J. Stewart, and M. D. Gwynne, "Masai and Kipsigis notes on east African plants: part iii: medicinal uses of plants," East African Agricultural and Forestry Journal, vol. 32, no. 2, pp. 200-327, 1966. 
[54] C. N. Muthaura, G. M. Rukunga, S. C. Chhabra et al., "Traditional phytotherapy of some remedies used in treatment of malaria in Meru district of Kenya," South African Journal of Botany, vol. 73, no. 3, pp. 402-411, 2007.

[55] C. N. Muthaura, G. M. Rukunga, S. C. Chhabra et al., "Antimalarial activity of some plants traditionally used in Meru district of Kenya," Phytotherapy Research, vol. 21, no. 9, pp. 860-867, 2007.

[56] C. N. Muthaura, J. M. Keriko, C. Mutai et al., "Antiplasmodial potential of traditional phytotherapy of some remedies used in treatment of malaria in Meru-Tharaka Nithi county of Kenya," Journal of Ethnopharmacology, vol. 175, pp. 315-323, 2015.

[57] O. Amuka, J. M. Mulei, and B. P. Gatwiri, "A brief ethnobotanical survey of some medicinal plants used by the Kanjoo community in Meru County, Kenya," Advances of Biotechnology and Microbiology, vol. 5, no. 1, article 555654, 2017.

[58] E. W. Ngari, L. W. Chiuri, S. T. Kariuki et al., "Ethnomedicine of Ogiek of river Njoro watershed, Nakuru-Kenya," Ethnobotany Research Applications, vol. 8, pp. 135-152, 2010.

[59] M. E. M. Saeed, H. Abdelgadir, H. Sugimoto et al., "Cytotoxicity of 35 medicinal plants from Sudan towards sensitive and multidrug-resistant cancer cells," Journal of Ethnopharmacology, vol. 174, pp. 644-658, 2015.

[60] D. W. Bishay, E. Y. Backheet, Y. G. Gouda et al., "Phytochemical and biological study of Vangueria edulis cultivated in Egypt," Bulletin of Pharmaceutical Sciences, vol. 35, no. 1, pp. 67-81, 2012.

[61] S. Mongrand, A. Badoc, B. Patouille et al., "Chemotaxonomy of the Rubiaceae family based on leaf fatty acid composition," Phytochemistry, vol. 66, no. 5, pp. 549-559, 2005.

[62] A. A. Mariod, B. Matthaüs, K. Eichner et al., "Study of fatty acids, tocopherol, sterols, phenolic compounds and oxidative stability of three unconventional oils in comparison with four conventional ones," Arab Journal of Food Nut, vol. 23, pp. 50-55, 2009.

[63] D. M. Pereira, P. Valentão, J. A. Pereira et al., "Phenolics: from chemistry to biology," Molecules, vol. 14, pp. 2202-2211, 2009.

[64] T. P. T. Cushnie and A. J. Lamb, "Recent advances in understanding the antibacterial properties of flavonoids," International Journal of Antimicrobial Agents, vol. 38, no. 2, pp. 99-107, 2011.

[65] D. Procházková, I. Bousová, N. Wilhelmová et al., “Antioxidant and prooxidant properties of flavonoids," Fitoterapia, vol. 82, no. 4, pp. 513-523, 2011.

[66] F. M. F. Roleira, E. J. Tavares-da-Silva, C. L. Varela et al., "Plant derived and dietary phenolic antioxidants: anticancer properties," Food Chemistry, vol. 183, pp. 235-258, 2015.

[67] J. N. Kabera, E. Semana, E. R. Mussa et al., "Plant secondary metabolites: biosynthesis, classification, function and pharmacological properties," Journal of Pharmacy and Pharmacology, vol. 2, no. 7, pp. 377-392, 2014.

[68] P. Benatti, G. Peluso, R. Nicolai et al., "Polyunsaturated fatty acids: biochemical, nutritional and epigenetic properties," Journal of the American College of Nutrition, vol. 23, no. 4, pp. 281-302, 2004.

[69] X.-C. Li, M. R. Jacob, S. I. Khan et al., "Potent in vitro antifungal activities of naturally occurring acetylenic acids," Antimicrobial Agents and Chemotherapy, vol. 52, no. 7, pp. 2442-2448, 2008.

[70] S. Terés, G. Barceló-Coblijn, M. Benet et al., "Oleic acid content is responsible for the reduction in blood pressure induced by olive oil," Proceedings of the National Academy of Sciences, vol. 105, no. 37, pp. 13811-13816, 2008.
[71] A. P. Desbois and V. J. Smith, “Antibacterial free fatty acids: activities, mechanisms of action and biotechnological potential," Applied Microbiology and Biotechnology, vol. 85, no. 6, pp. 1629-1642, 2010.

[72] M. F. Mahomoodally and S. Dilmohamed, "Antibacterial and antibiotic potentiating activity of Vangueria madagascariensis leaves and ripe fruit pericarp against human pathogenic clinical bacterial isolates," Journal of Traditional and Complementary Medicine, vol. 6, no. 4, pp. 399-403, 2016.

[73] M. N. Beidokhti, D. Staerk, A. K. Jåger et al., "Inhibitory potential of 40 medicinal plant extracts from Madagascar against enzymes linked to type 2 diabetes," Planta Medica, vol. 81 , no. $16,2015$.

[74] A. Karim, M. Dalia, A. M. S. Kamal et al., "Antifungal acetylated flavonol from the Sudanese material of Vangueria madagascariensis Rubiaceae," World Journal of Pharmaceutical and Life Sciences, vol. 3, no. 8, pp. 139-143, 2017. 


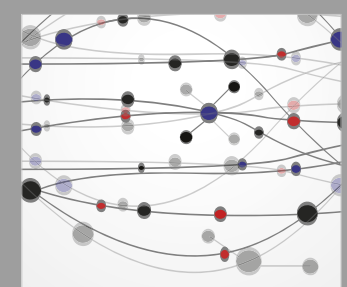

The Scientific World Journal
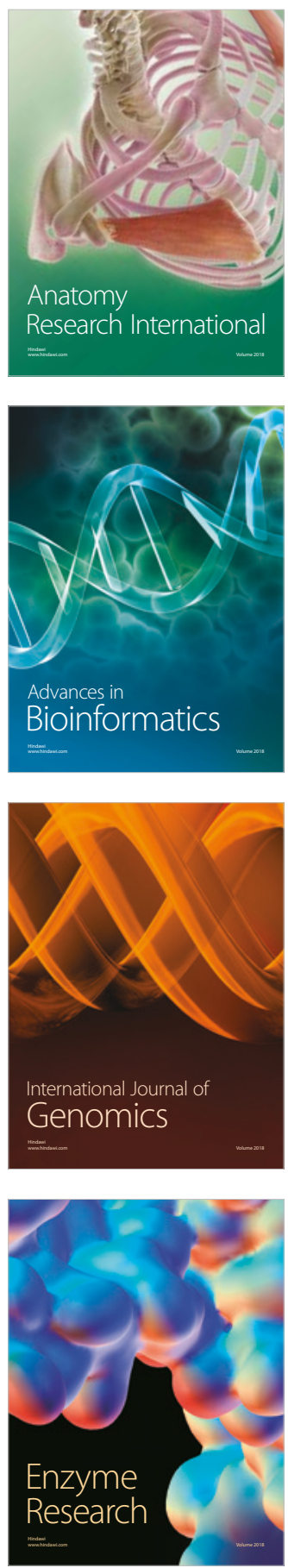
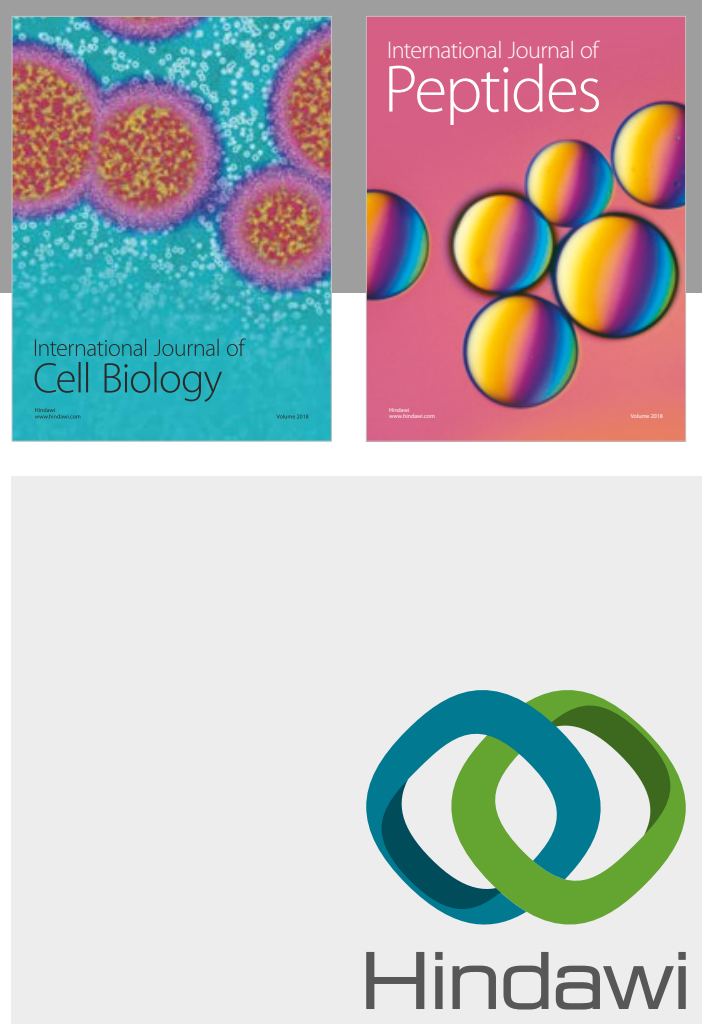

Submit your manuscripts at

www.hindawi.com
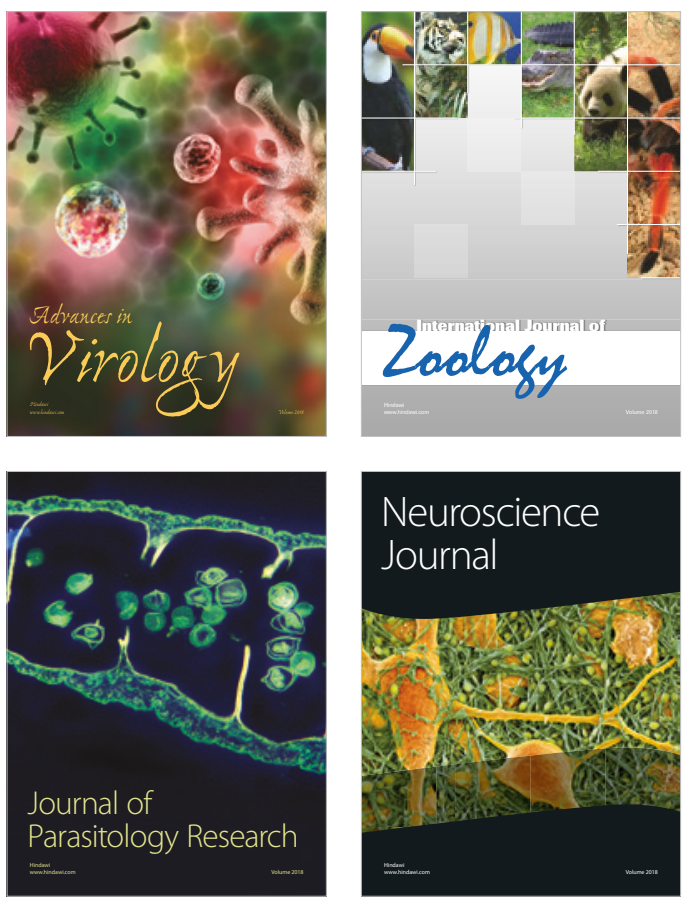
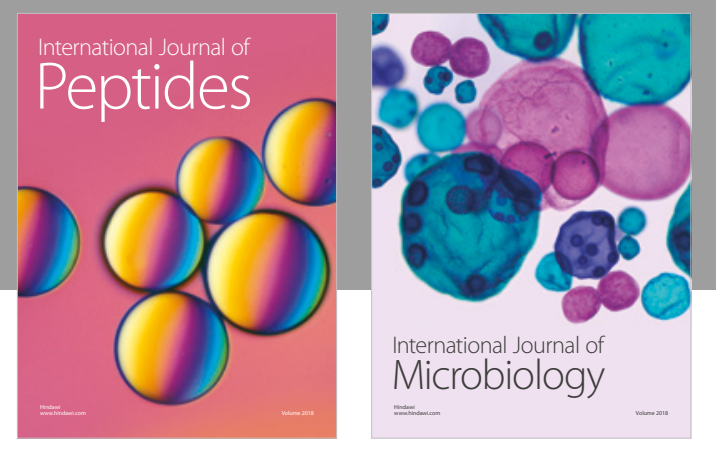

nternational Journal of Microbiology
Journal of
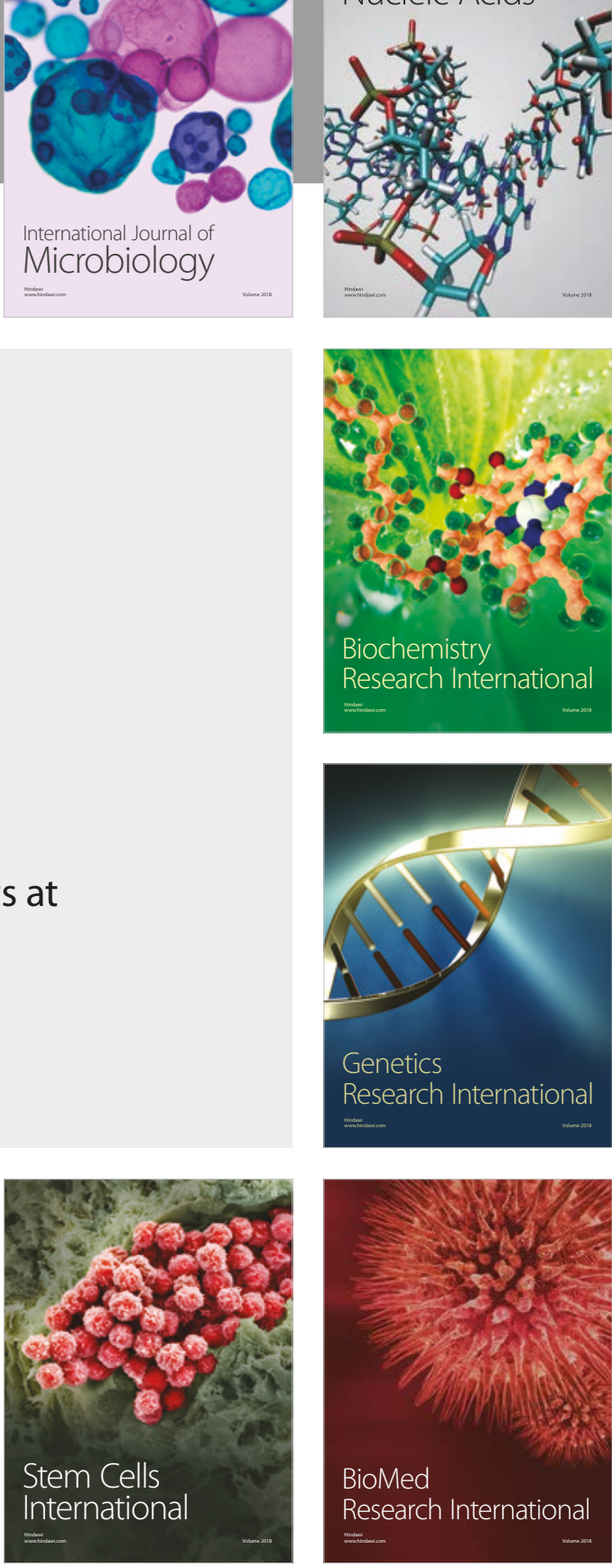
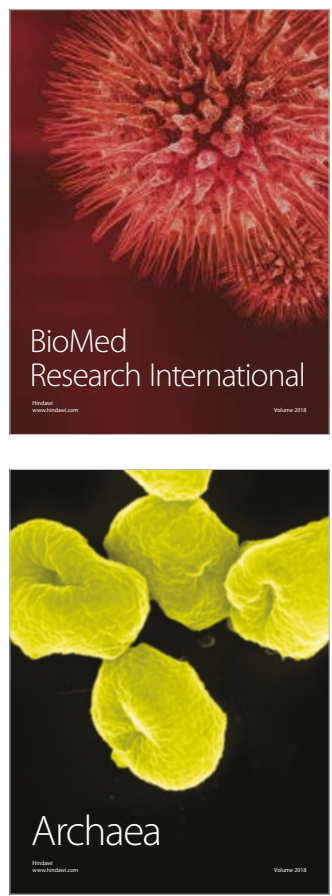